\title{
Impact of dust size parameterizations on aerosol burden and radiative forcing in $\mathrm{RegCM} 4$
}

\author{
Athanasios Tsikerdekis ${ }^{1}$, Prodromos Zanis ${ }^{1}$, Allison L. Steiner ${ }^{2}$, Fabien Solmon ${ }^{3}$, Vassilis Amiridis $^{4}$, \\ Eleni Marinou ${ }^{4,5}$, Eleni Katragkou ${ }^{1}$, Theodoros Karacostas ${ }^{1}$, and Gilles Foret ${ }^{6}$ \\ ${ }^{1}$ Department of Meteorology and Climatology, School of Geology, Aristotle University of Thessaloniki, \\ 54124 Thessaloniki, Greece \\ ${ }^{2}$ Atmospheric, Oceanic and Space Sciences, University of Michigan, Ann Arbor, MI 48109, USA \\ ${ }^{3}$ Earth System Physics Section, The Abdus Salam International Centre for Theoretical Physics, 34100 Trieste, Italy \\ ${ }^{4}$ Institute for Astronomy, Astrophysics, Space Application and Remote Sensing, National Observatory of Athens, \\ 15236 Athens, Greece \\ ${ }^{5}$ Department of Physics, Aristotle University of Thessaloniki, 54124 Thessaloniki, Greece \\ ${ }^{6}$ Laboratoire Inter-universitaire des Systèmes Atmosphériques (LISA), UMR7583, Universités Paris-Est Créteil et \\ Paris Diderot, CNRS, Créteil, France
}

Correspondence to: Athanasios Tsikerdekis (tsike@geo.auth.gr)

Received: 20 May 2016 - Published in Atmos. Chem. Phys. Discuss.: 27 July 2016

Revised: 21 December 2016 - Accepted: 21 December 2016 - Published: 18 January 2017

\begin{abstract}
We investigate the sensitivity of aerosol representation in the regional climate model RegCM4 for two dust parameterizations for the period 2007-2014 over the Sahara and the Mediterranean. We apply two discretization methods of the dust size distribution keeping the total mass constant: (1) the default RegCM4 4-bin approach, where the size range of each bin is calculated using an equal, logarithmic separation of the total size range of dust, using the diameter of dust particles, and (2) a newly implemented 12-bin approach with each bin defined according to an isogradient method where the size ranges are dependent on the dry deposition velocity of dust particles. Increasing the number of transported dust size bins theoretically improves the representation of the physical properties of dust particles within the same size bin. Thus, more size bins improve the simulation of atmospheric processes. The radiative effects of dust over the area are discussed and evaluated with the CALIPSO dust optical depth (DOD). This study is among the first studies evaluating the vertical profile of simulated dust with a pure dust product. Reanalysis winds from ERA-Interim and the total precipitation flux from the Climate Research Unit (CRU) observational gridded database are used to evaluate and explain the discrepancies between model and observations. The new dust binning approach increases the dust column burden by 4
\end{abstract}

and $3 \%$ for fine and coarse particles, respectively, which increases DOD by $10 \%$ over the desert and the Mediterranean. Consequently, negative shortwave radiative forcing (RF) is enhanced by more than $10 \%$ at the top of the atmosphere and by 1 to $5 \%$ on the surface. Positive longwave RF locally increases by more than $0.1 \mathrm{~W} \mathrm{~m}^{-2}$ in a large portion of the Sahara, the northern part of the Arabian Peninsula and the Middle East. The four-bin isolog method is to some extent numerically efficient, nevertheless our work highlights that the simplified representation of the four-bin approach produces less dust optical depth and RF, a fact that should be taken into account by future studies of the same region.

\section{Introduction}

Aerosols affect the energy budget of the planet through numerous feedback mechanisms. The direct aerosol climatic impact of $-0.27 \mathrm{~W} \mathrm{~m}^{-2}$ and the indirect effect of $-0.55 \mathrm{~W} \mathrm{~m}^{-2}$ was estimated in the most recent IPCC report, yet the forcing uncertainty remains the highest among all the other factors (Boucher et al., 2013). Aerosols strongly affect Earth's climate by scattering and absorbing the incoming solar radiation (direct effect), burn low clouds through long- 
wave heating (semi-direct effect) or by producing brighter clouds (first indirect effect) with longer cloud lifetime (second indirect effect; Bangert et al., 2012; Hansen et al., 1997; Karydis et al., 2011; Lohmann and Feichter, 2001; Nabat et al., 2014; Ramanathan et al., 2001; Tegen, 2003). Small particles can effectively scatter/reflect the incoming shortwave radiation, while large particles can more effectively absorb and re-emit on the longwave part of the spectrum (Liao and Seinfeld, 1998). Globally, dust is considered to have a slightly negative radiative forcing $-0.1 \mathrm{~W} \mathrm{~m}^{-2}(-0.3$ to $0.1 \mathrm{~W} \mathrm{~m}^{-2}$ ) on climate (Boucher et al., 2013). A recent detailed evaluation of RegCM4-CCM3 using satellite-based observations over the European domain showed that surface solar radiation bias can be attributed to an overestimation or underestimation of counteracting parameters, with cloud fractional cover, cloud optical thickness and aerosol optical depth (AOD) being the most important (Alexandri et al., 2015). Since airborne dust plays a fairly significant role in the total AOD, it is important to understand and improve the probable causes of dust optical depth biases.

Dust production begins when surface wind or wind at a certain height exceeds a threshold. In most studies, the threshold friction velocity is determined as the minimal wind velocity that is capable of sustaining particle movement (Iversen and White, 1982). Practical threshold wind velocity is dependent on soil particle size, inter-particle cohesion forces and surface roughness features. Assuming a constant particle density, soil particle size affects their weight. Thus, large particles require higher surface friction velocity to initiate dust movement. On the other hand, the interparticle forces (van der Waals, capillary, Coulomb forces) acting upon small dust species, that depend on soil moisture and chemical composition, are higher compared to the larger particles and difficult to estimate (Shao and Lu, 2000). Due to the opposite dependency of particle weight and interparticle cohesion forces, particles with a diameter of $60 \mu \mathrm{m}$ were estimated to have the minimum wind erosion threshold (Knippertz and Stuut, 2014). Particles of this size have a higher probability to be emitted first and trigger the next stages of dust emission (saltation and disaggregation).

Mineral dust is produced mainly in deserts. Its production depends on surface wind, precipitation and changes in the vegetation cover (Tegen et al., 2000). The Sahara is the most important source of aeolian soil dust on the planet (Prospero et al., 2002). Dust from the Sahara is transported northward to Europe and the Mediterranean in episodic events quite frequently (11.4 $\mathrm{yr}^{-1}$; Gkikas et al., 2013). The dust burden in the Mediterranean region differs spatially and seasonally, with the eastern Mediterranean experiencing high dust load in spring and the western Mediterranean reaching its peak in the summer and autumn (Moulin et al., 1998). The central Mediterranean can be considered a transition region where dust transport episodes can occur throughout spring to autumn (Israelevich et al., 2012). Depending on season and area of the Mediterranean, dust can originate from different places in the Sahara. Possible dust pathways have been identified for each season using the TOMS AI satellite data (Israelevich, 2003). In spring, for example, dust follows a long trajectory from the Bodélé Depression to southern Algeria and then moves northward across the coast of northern Africa to reach the eastern Mediterranean. This long path affects the size of soil particles that reach the Mediterranean in spring in comparison with other seasons. Since dust particles have to travel for such a long distance, dry deposition through gravitational settling forces coarse particles to deposit. Thus, the size of dust particles across the Mediterranean in the spring $(1.5 \mu \mathrm{m})$ is half of those particles during summer and autumn $(3 \mu \mathrm{m})$, which follow a shorter trajectory (Israelevich, 2003).

The vertical dust distribution has remained uncertain in the past decade because satellite measurement mainly provided the columnar AOD and the stationary observations were spatially sparse. Modeling studies have shown different vertical dust distribution between the Mediterranean, the Atlantic and the Sahara (Alpert et al., 2004), but after the launch of the CALIPSO satellite in 2006, our understanding on aerosol vertical distribution increased rapidly (Winker et al., 2009). The particle size distribution of dust changes over height, with finer particles reaching higher in the atmosphere and therefore having a higher probability to be transported further because wind speed also increases with height. Considering that the fine particles scatter and efficiently reflect the incoming solar radiation, we can grasp the importance of the vertical dust distribution on the shortwave radiative forcing.

An important component that affects the transport and the radiative properties of dust in climate modeling is the number of transport dust size bins. Small dust particles, due to their weight, can travel over long distances and can efficiently reflect/backscatter the incoming shortwave solar radiation, while larger particles, with a shorter atmospheric life, can effectively absorb and re-emit in the longwave spectrum. Thus, both the partitioning and the number of dust transport bins, used in atmospheric models, should carefully distinguish dust particles with contrasting radiative properties and transport characteristics. The number of dust bins and the size range resolved in global climate models vary between models, with most using 1-6 dust bins spanning a size range of 0.01-25 $\mu \mathrm{m}$ (e.g., Kinne, 2003; Huneeus et al., 2011, and references therein). A greater number of dust size bins improves particle dry deposition and thus allows for more accurate simulation of both the atmospheric dust burden and the interaction with radiation (Foret et al., 2006; Menut et al., 2007). However, the high computational requirements of global climate models demands as few as possible dust size aggregates and consequently a low size range of aerosol species. Regional climate models with smaller domains of interest usually simulate between 4 and 12 dust size bins (e.g., Alexandri et al., 2015; Basart et al., 2012; Giorgi et al., 2012; Nabat et al., 2012; Solmon et al., 2008; Spyrou et al., 2013; Zakey et al., 2006), while dust transport models 
have conducted simulation experiments with up to 40 dust bins (Menut et al., 2007).

Dust particle size measurements in the Sahara from the Fennec 2011 aircraft campaign show that the dust coarsemode volume median diameter ranges between 5.8 and $45.3 \mu \mathrm{m}$ (Ryder et al., 2013). As one moves away from the dust source regions, the mean/median size of dust particles drops dramatically. In the Mediterranean the mean diameter of dust particles ranges between 2 and $30 \mu \mathrm{m}$ (Goudie and Middleton, 2001, and references therein). It is evident that particles with a diameter $>25 \mu \mathrm{m}$ possess a major role in the burden of dust close and in some cases away from the dust sources. Thus, Foret et al. (2006) proposed that dust size for the transported bins should range from 0.09 to $63 \mu \mathrm{m}$, considering both the total number and the mass distribution of soil particles.

This study presents new dust features in RegCM4, highlights the sensitivity of dust emission and deposition processes with various meteorological schemes, and analyzes the effect of size bin distribution on dust burden and radiative forcing. In Sect. 2 we describe the regional climate model RegCM4 and the gridded observational data from LIVAS, ERA-Interim and CRU. We discuss previous studies on dust size parameterization and explain how the present work expands these studies further. In Sect. 3 we evaluate the regional climate model RegCM4 using the dust product LIVAS, where high-resolution vertical aerosol extinction coefficient measurements were made available and new techniques for the discrimination of pure dust were developed (Amiridis et al., 2013). We also highlight the importance of the partitioning method and the number of dust size bins by comparing two simulations in terms of the dust column burden and dust optical depth. Finally, we discuss the effect of the two binning methods on the dust radiative forcing both in the short- and the longwave spectrum.

\section{Material and methods}

\section{$2.1 \quad$ RegCM4}

The Regional Climate Model (RegCM) is a space-limited numerical model developed at the National Center for Atmospheric Research (NCAR) and the Abdus Salam International Centre for Theoretical Physics (ICTP). Notably, it was the first area-limited model used for long-term climate simulations (Giorgi and Anyah, 2012). Here we employ RegCM4, which is described in detail in Giorgi et al. (2012). The hydrostatic core of the model, which is based on the fifth version of the PSU/NCAR Mesoscale Model (MM5; Grell et al., 1994), restricts the minimum horizontal resolution of the model to $10 \mathrm{~km}$. Thus, the regional-scale convective precipitation on RegCM4 is resolved through various convective scheme parameterizations. The vertical computation of the atmosphere is applied on sigma levels. Land-atmosphere interactions are analyzed with the Biosphere-Atmosphere Transfer Scheme (BATS; Dickinson et al., 1993), but there is a recently implemented alternative option to use the Community Land Model (CLM4.5; Oleson et al., 2013). The radiation transfer scheme used in RegCM4 is based on the NCAR Community Climate Model version 3 (CCM3; Kiehl et al., 1996) with the additional option of the correlated-k rapid radiation transfer model (RRTM; Mlawer and Clough, 1997; Mlawer et al., 1997) to improve the model representation of the radiation processes in the longwave spectrum (Iacono et al., 2000).

The chemical part of the model contains gas-phase chemistry (Shalaby et al., 2012; Steiner et al., 2014) as well as natural and anthropogenic aerosols (Solmon et al., 2006; Zakey et al., 2006, 2008). Most of the natural aerosols, such as dust and sea salt, are driven by RegCM4 meteorology, while all anthropogenic aerosols, organic carbon, black carbon and pollen require emission datasets.

The dust emission scheme is activated in a grid cell when the friction velocity, resolved as a function of RegCM4 simulated wind speed and surface roughness, is higher than the minimum friction velocity threshold. Dust saltation flux is calculated following Marticorena and Bergametti (1995) and Zakey et al. (2006), while the calculation of dust aerosol vertical flux from the saltation flux follows Laurent et al. (2008).

Particle size distribution (PSD) of the emitted dust and its relation to surface wind conditions can be modeled using either Alfaro and Gomes (2001) or Kok (2011a) theory. The first theory, based on wind tunnel experiments, demonstrated that increasing wind speed close to the surface increases the portion of fine dust particles emitted (Alfaro et al., 1997). Based on these results, Alfaro and Gomes (2001) suggested that the saltator kinetic energy increases with wind speed, and thus the impact produces more fine particles and affects the PSD of dust. On the other hand, Kok (2011a) showed the impact of saltator on the surface to act as the fragmentation of brittle materials and suggested that the saltator impact speed does not depend on wind friction speed (Kok, 2011b). Using observational data, he established a theoretical expression of particle size distribution independent of surface wind speed. Kok PSD theory shows a significant improvement of the simulated RegCM4 dust optical depth over the European and northern African domain (Nabat et al., 2012); thus, we use this parameterization in these simulations.

Surface roughness and soil moisture, which are essential for the calculation of threshold friction velocity and saltation fluxes, are provided by the surface scheme BATS (Zakey et al., 2006). The soil aggregate distribution used to determine threshold velocity and the saltation flux differs from Zakey et al. (2006) and is taken from Menut et al. (2013), based on the FAO texture class and spatial distribution. Emission processes take place only over desert or semidesert grid cells. RegCM4 also accounts for possible subgrid partial desert cover emissions on grid cells dominated by different types of soil and soil texture. 

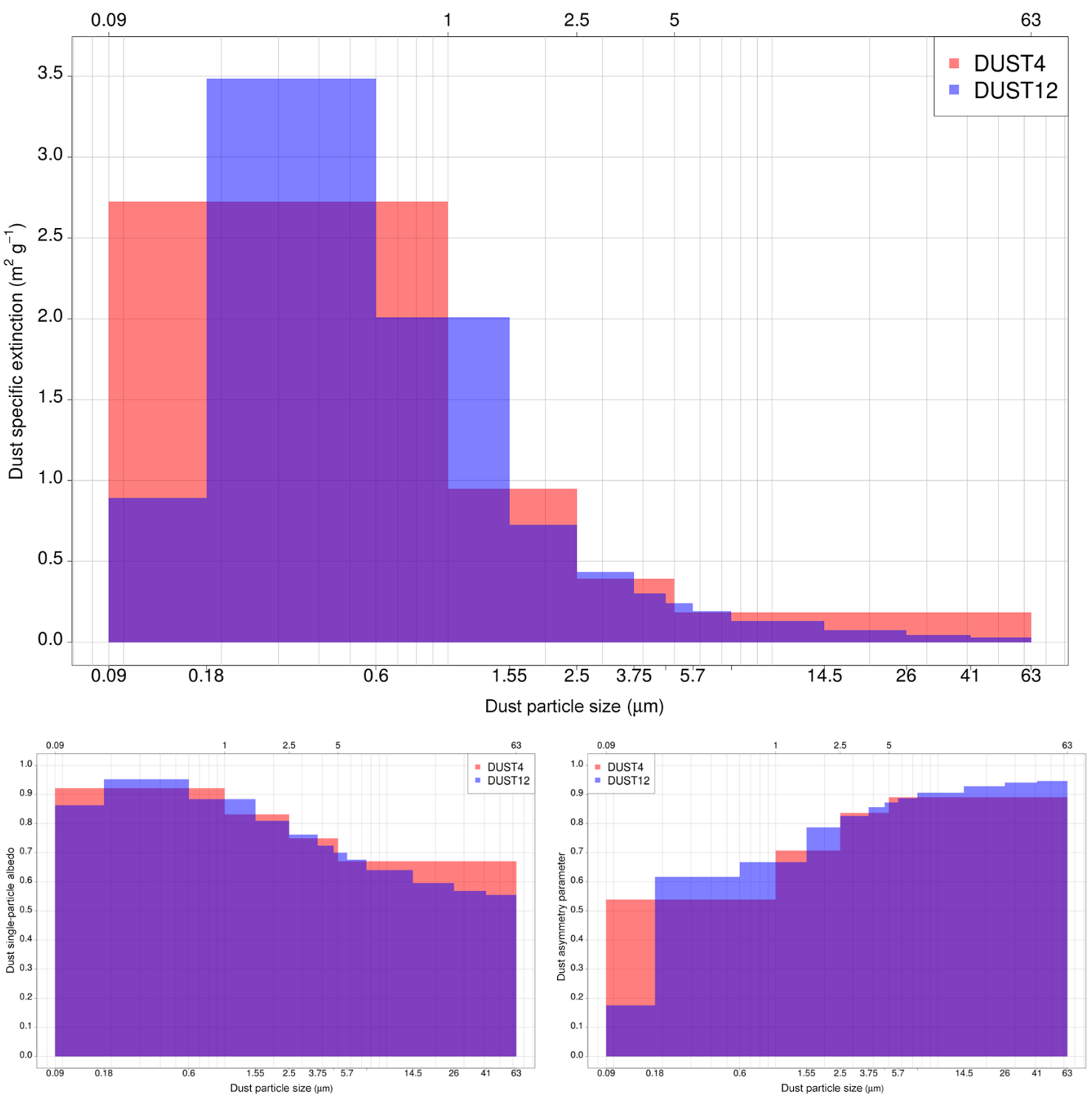

Figure 1. Dust bin specific extinction coefficient, single-scattering albedo (SSA) and particle asymmetry parameter on the 350-640 nm spectral band. Red coloring represents the 4-bin experiment and blue the 12-bin experiment. The top and bottom axes represent the dust particle diameter limits of the 4 and 12 dust size bins, respectively.

Following the calculation of the dust mass emission fluxes, the tracer transport equation is applied for each transported bin (Solmon et al., 2006). The equation includes transport of the tracers through resolvable winds, horizontal and vertical turbulent diffusion, and vertical transport due to cumulus convection. The default number of dust size bins that are resolved for transportation in RegCM4 is four (Zakey et al., 2006), with the selection of each size bin defined according to the diameter of dust particles. The size range of each bin is calculated using an equal, logarithmic separation of the total size range of dust, using the diameter of dust particles. This method creates some biases that depend on how representative the selected size bins are compared to the actual dust particle size distribution in each bin. Following the methodology of Foret et al. (2006), we have implemented a new dust size discretization scheme that resolves 12 dust transport size bins instead of 4 . The specification of each bin is linked to the gradient of dry deposition velocity as a function of particle diameter. When the change rate of dry deposition velocity to particle size is high, more bins are created on that specified size range, while the opposite happens when the rate changes are slower. The improved partitioning of dust size bins as well as the higher number of bins theoretically enhances the representation of physical removal processes during transport, the estimation of the effective radius of dust particles and the calculation of dust optical properties. Each 
transported bin is considered a distinct tracer, which assumes that there is no mixing between the dust size bins.

Removal processes through dry deposition and wet deposition (washout) are included in the model. Dry deposition includes gravitational settling (a function of particle size and density), Brownian diffusion (acts mainly on small particles close to the ground) and turbulent transfer, as well as impaction, interception and particle rebound (Zhang, 2001). Wet deposition processes include a size-dependent washout scavenging parameterization (Gong, 2003; Seinfeld and Pandis, 1998) and occurs for a small fraction of dust (10\%) considered soluble.

The optical properties of dust are pre-calculated for every size bin and each spectral band of the radiation scheme in use (CCM3 or RRTM) using Mie theory. Due to the high nonlinearity of the Mie calculation, we calculated optical properties for each bin and each spectral band, based on a weighted average on size and wavelength assuming that the sub-size distribution follows Kok (2011a), consistent with the emission size distribution. We ensure that the 12- and 4-bin options cover the exact same total size range and that the integrated optical properties over the whole distribution are conserved regardless of the number of bins. Figure 1 depicts the dust specific extinction coefficient, single-scattering albedo and asymmetry parameter for both binning options. The differences for all the optical parameters are relatively small because the calculations were performed for multiple effective particle radii within the range of each size bin and averaged in the end, instead of using the mean effective radius of each size bin (Fig. S1 in the Supplement). Using this method, we ensured that the optical properties between the two experiments are almost identical.

In our simulation, we use the default radiation scheme CCM3 to retain the same meteorological fields between the two binning experiments. In the current version of RegCM4, the RRTM scheme calculates cloud-radiation interaction using the Monte Carlo independent-column approximation (McICA; Pincus, 2003) method. The McICA method, although it provides a more detailed and complicated perspective on the horizontal and vertical radiative structure of the clouds, introduces randomly generated noise even when simulating the exact same experiment. In his work, Pincus (2003) accurately highlights that this randomly generated noise can be significantly reduced to zero with enough ensemble members. However, sensitivity tests with RegCM4 show that the changes in the radiative effect between the two dust bin partitioning methods are already small; thus, the results can be significantly altered even with the small perturbation contained in an ensemble mean. A downside of the CCM3 scheme is the simplistic representation of the longwave spectrum as far as the dust particles. In Sect. 3.3 we discuss the relevant impact of the binning methods in the longwave radiative spectrum between the two radiative transfer schemes.

\subsection{LIVAS}

The "LIdar climatology of Vertical Aerosol Structure for space-based lidar simulation studies" (LIVAS; Amiridis et al., 2015) is a three-dimensional global climatic dataset derived from CALIPSO measurements and funded by the European Space Agency (ESA). CALIPSO obtains highresolution profiles of the attenuated backscatter of aerosols and clouds at 532 and $1064 \mathrm{~nm}$ and retrieves aerosol optical properties below optically thin clouds, in clear skies and above clouds (Winker et al., 2009). Thus, in regions with frequent optically thick clouds, aerosol measurements are limited. In regions with an absence of clouds like the Sahara, measurements of aerosol species (most likely dust) are available more frequently.

LIVAS utilizes the level 2 (version 3) product of CALIOP measurements (Amiridis et al., 2015). The CALIPSO level 2 database determines the vertical location of cloud/aerosol layers (Vaughan et al., 2009), distinguishes the clouds from the aerosol layers (Liu et al., 2009), separates aerosol layers into six subcategories (dust, marine, smoke, polluted dust, polluted continental and clean continental; Omar et al., 2009) and calculates the AOD for each selected layer (Young and Vaughan, 2009).

The LIVAS extinction dust product is corrected for the lidar ratio (LR) based on multi-year measurements performed by the ground-based lidar stations of the EARLINET lidar network (https://www.earlinet.org) and intensive campaigns in different dust regions around the globe (Wandinger et al., 2010; Hänel et al., 2012; Baars et al., 2016). The LR of dust particles depends on their refractive index and may vary for aerosols of the same type. The refractive index values rely upon the composition of dust and most importantly on the relative proportion of clay-sized mineral illite in dust (Schuster et al., 2012). Thus, regions with different physicochemical dust characteristics leads to different LR values. Version 0.3.1 of LIVAS separates the globe into three regions, specified based on known dust sources and loadings with specific physio-chemical composition and LR for each region. The globally LR value $40 \mathrm{sr}$ used in CALIPSO retrieval algorithm (Omar et al., 2009) was replaced with region specific LRs of 40,50 and $55 \mathrm{sr}$ (Fig. S2).

LIVAS has been evaluated against AERONET stations globally by Amiridis et al. (2015). The results show that the AOD differences are between +0.1 and -0.1 in most cases. Over the southwestern Sahara, LIVAS underestimates the AERONET AOD by -0.1 , and this bias may be related to the dust underestimation of CALIPSO found in previous studies (Amiridis et al., 2013; Schuster et al., 2012; Tesche et al., 2013; Wandinger et al., 2010). Amiridis et al. (2013) showed that LIVAS correlates well with the Dark Target MODIS retrieval over the sea, yet the correlation between MODIS Deep Blue (C5 version) and LIVAS over the Sahara is weak (results not shown). The new version of MODIS Deep Blue (C6) improved its retrieval accuracy and spatial 
coverage globally (Sayer et al., 2014, 2015) and the Mediterranean region (Georgoulias et al., 2016a) in comparison to AERONET. Thus, further research is needed to determine the correlation between LIVAS dust optical depth (DOD) and MODIS Deep Blue (C6) AOD. Furthermore, Georgoulias et al. (2016b) showed that LIVAS correlates well with the highresolution TERRA MODIS and MACC dust optical depth over land-covered regions in the eastern Mediterranean.

Monthly mean LIVAS data are available at a $1^{\circ} \times 1^{\circ}$ horizontal resolution with a vertical resolution ranging from $60 \mathrm{~m}$ $(-0.5$ and $21 \mathrm{~km}$ ) to $180 \mathrm{~m}$ (above $21 \mathrm{~km}$; Amiridis et al., 2015). We concentrate on the troposphere where the vertical distribution of layers is constant. In our work we use the specialized LIVAS pure dust product, which includes the extinction coefficient of pure dust calculated from the dust percentage of "dust" and "polluted dust" aerosol subcategories of CALIPSO (Amiridis et al., 2013). Since CALIPSO is a nongeostationary satellite, the obtained mean monthly profiles are highly dependent on the date and time the measurements were taken. Thus, a spatiotemporal mask was produced according to the exact flight track of CALIPSO and applied to the nearest $\mathrm{RegCM}$ time step prior to evaluation.

\subsection{Meteorological data}

ERA-Interim is a state-of-the-art global atmospheric reanalysis product developed by the European Centre for MediumRange Weather Forecasts (ECMWF; Dee et al., 2011). The data assimilation system uses various types of observational data from ground-based stations, radiosondes, ships and satellites. Data availability starts from 1979 and is extended forward in near-real time. Its assimilation scheme uses a $12 \mathrm{~h}$ cycle, where observational data are combined with forecast information from the previous time step in order to construct the global atmospheric conditions. ERA-Interim reanalysis database is exceptionally useful over isolated areas like the Sahara, where meteorological measurements are limited. Wind velocity and direction, associated with dust emission and transport, were used to evaluate RegCM4 wind fields. ERA-Interim is also used for boundary conditions in several regional climate models (e.g., RegCM4) for hindcast simulations.

Climate Research Unit (CRU) data are a gridded global climate database of monthly meteorological measurements from ground-based stations (Harris et al., 2014). The dataset includes surface measurements of six meteorological variables, notably precipitation and temperature. Stations are interpolated into a $0.5 \times 0.5$ grid that covers all of the land surface of the planet (except Antarctica). Data availability peaks between the period 1950 and 2000 and drops dramatically in the last decade. During the period 2007-2014 and around the area of the Sahara, more than 600 monthly measurements of precipitation are included in the database from various stations. However, we note that most of the continual measure- ments occur at stations close to the border of the desert, and station coverage is generally limited over the Sahara.

\subsection{Dust particle size discretization}

Dust tracers in climate models are usually represented by describing the size distribution with a specified number of bins defined according to the dust particle diameter $(D)$. Increasing the number of transported dust size bins improves the representation of the physical properties and behavior of dust particles within same bin. However, the computational cost, especially in climate studies, generally limits the number of bins used to describe (dust). The transported size bins must be separated into an affordable number of bins and with a method that minimizes the numerical inaccuracies due to dust bin partitioning.

The isolog method, which partitions the dust bins into an equal range of $\log D$, is frequently used to specify the range of the dust size bins in climate models (Huneeus et al., 2011, and references therein). An alternative partitioning method was introduced in Foret et al. (2006), who divide the total size range in each bin according to the changes in dry deposition velocity with size. Using a simple one-dimensional box model they simulated an experiment with a detailed particles size distribution that used 1000 size bins within the range of $0.001-100 \mu \mathrm{m}$ diameter. They used this experiment as a reference to evaluate the differences between the isolog and isogradient method. The error ratio between the total dust particle mass (or number) simulated with the given particle size bin scheme (isolog or isogradient) and bin number (4-30 bins) and the total dust particle mass (or number) simulated with the reference size distribution (1000 bins), showed that, for a given number of bins, the isogradient scheme scored much better in terms of total dust mass, but the isolog scheme produced somewhat better results in terms of total dust particle number. The isogradient method yielded errors lower than $2 \%$ with regard to the total particle number and the representation of AOD when using more than eight dust bins (Foret et al., 2006).

Following the above results, Menut et al. (2007) implemented the isogradient scheme into the 4-D transport model CHIMERE-DUST and performed several nested simulations over the Sahara region. To exclude any biases introduced by the emission, deposition and dynamics of the model they evaluated their results using a reference simulation that resolved 40 size bins. They concluded that the isogradient scheme reduced the errors by a factor of 2 compared to the isolog method and that six size bins are not sufficient to reproduce the correct concentration levels of dust even with the methodology proposed by Foret et al. (2006).

Both of these studies have shown that using a higher number of bins and the use of isogradient scheme improves the validity of the simulated results. However, they evaluate only the effect of dust bin partitioning on the size distribution dust emissions, either with a simple one-box model (Foret 


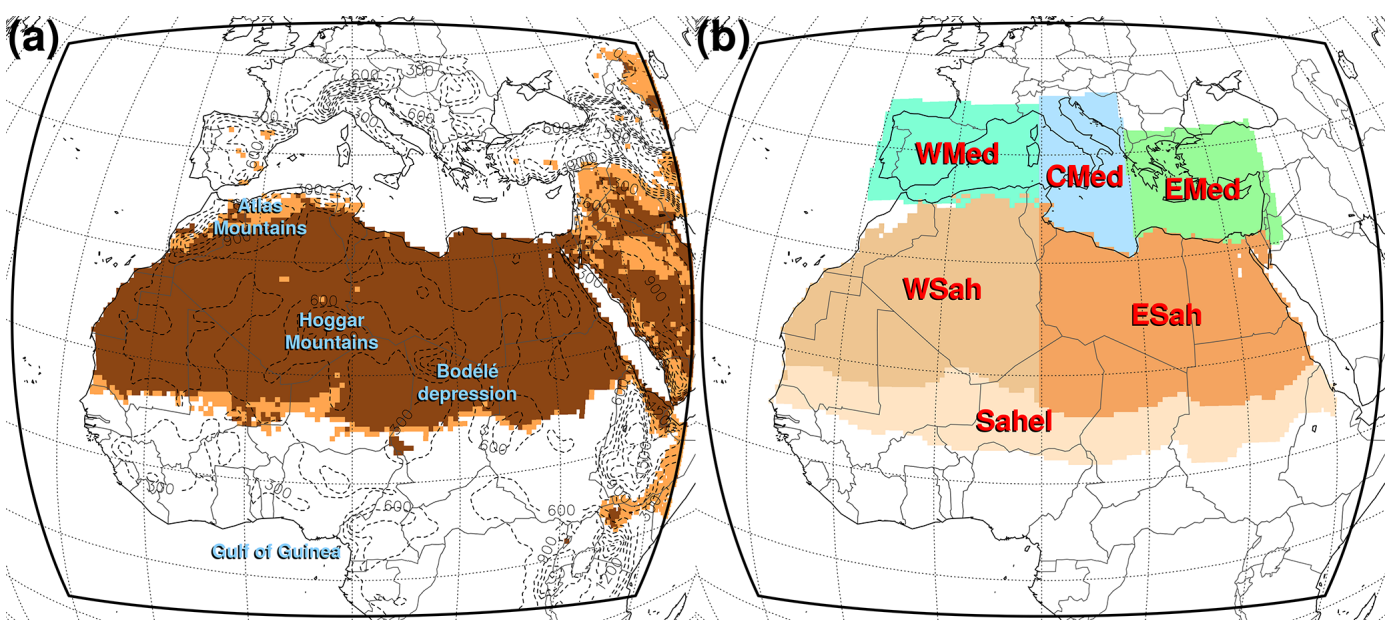

Figure 2. RegCM4 simulated domain (solid black contour) and the subregions selected for the analysis (blue contours). Background colors represent the desert (dark brown) and semidesert (light brown) grid cells assigned by the model. Dashed lines illustrate the simulated topography used on RegCM4 in meters.

(a) LIVAS, dust optical depth

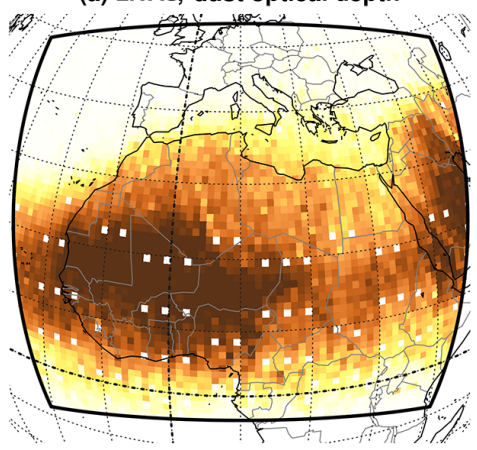

(b) DUST4, dust optical depth

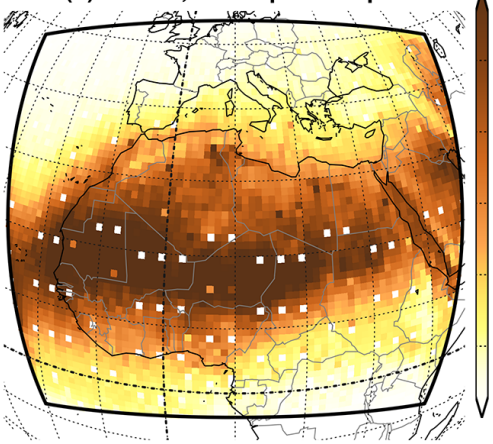

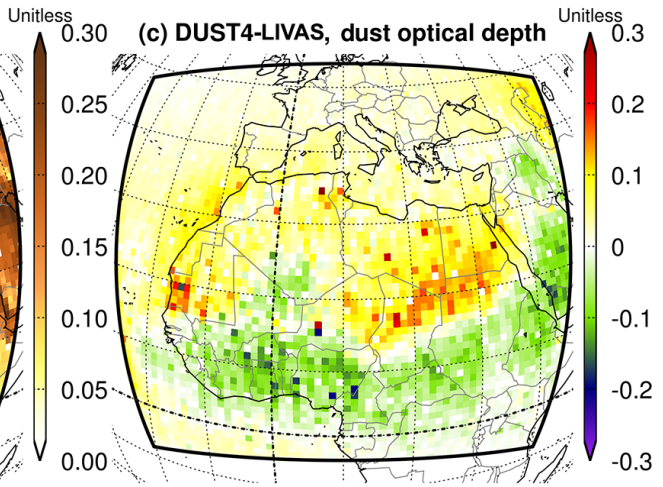

Figure 3. Dust optical depth of the DUST4 experiment and the LIVAS dust product for the period January 2007 to November 2014.

et al., 2006) or a three-dimensional dust transport model (CHIMERE-DUST; Menut et al., 2007). In this paper, we take this research further by comparing the method and number of dust size bins with in RegCM4 results, and we perform evaluations using observational data, account for biases introduced by the balance of production and loss processes, calculate optical properties of dust and evaluate these results with satellite products.

\subsection{Experimental setup}

The key parameters of the RegCM4 simulations are presented in the Table 1. The simulation domain includes the Sahara and the largest part of the Arabian Peninsula (Fig. 2), which captures the two main sources of dust on Earth (Tegen, 2003). To reduce the contribution of dust from outside the domain requiring chemical lateral boundary conditions, the domain extends south of the Sahara. The simulated domain was separated into six distinct subregions: the Sahel, eastern Sahara (ESah), western Sahara (WSah), eastern Mediter- ranean (EMed), central Mediterranean (CMed) and western Mediterranean (WMed; Fig. 2b). The Sahel was delimited using CRU precipitation for the period 2001-2014. The selected grid cells receive annual precipitation between 100 and $600 \mathrm{~mm}$ (Ali and Lebel, 2009; Nicholson, 2013) and are located in the southern border of the Sahara. The eastern and western Sahara were selected according to the desert and semidesert land use assigned by the model. Their southern borders were masked by the Sahel grid points. The three Mediterranean subregions contain only non-desert grid points and are separated according to their DOD seasonality (Israelevich et al., 2012). Two 8-year simulations (4 dust size bins and 12 dust size bins) were performed from September 2006 to November 2014, excluding in our analysis the initial 3 months as a spin-up time. The 4-dust-bin experiment (DUST4) implements the isolog approach for the partitioning of the dust size bins, while the 12-dust-bin experiment (DUST12) uses the isogradient method. Both experiments use the Kok (2011a) dust particle size distribution theory. 
(a) Western Mediterranean

(b) Central Mediterranean

(c) Eastern Mediterranean

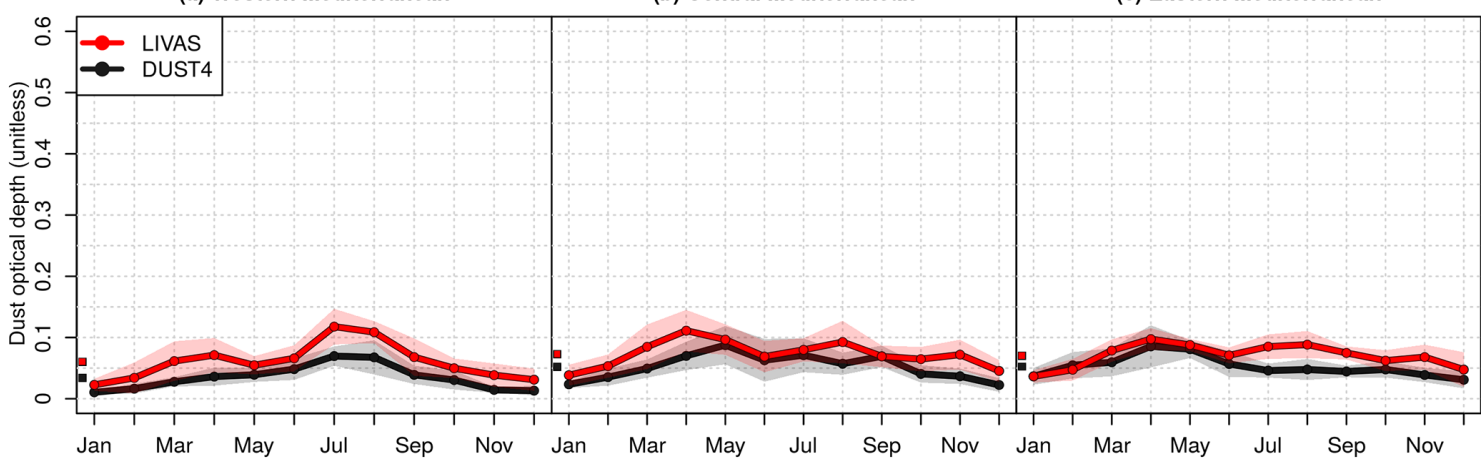

(d) Western Sahara

(e) Eastern Sahara

(f) Sahel

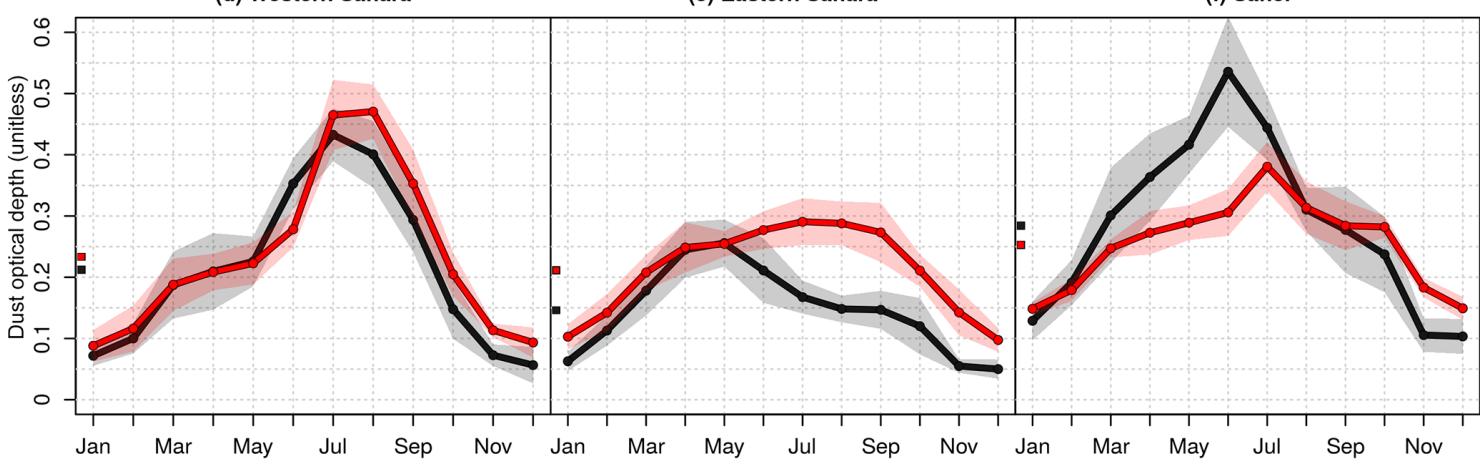

Figure 4. Dust optical depth annual cycle of LIVAS and DUST4 experiment for the period January 2007 to November 2014 . Shaded areas display the $95 \%$ confidence interval of the mean.

To ensure that the two experiments are identical in every way except the dust bin number and partitioning method, we have both distributions span the exact same total size range and conserve the integrated optical properties (over the whole distribution) regardless of whether we consider 4 or 12 bins. Furthermore, there is no interaction between the dust particles and the radiation fields (e.g., no direct aerosol feedback on climate) in order to ensure that there are no meteorologically driven changes between the two simulations. The radiative forcing of dust is calculated using a separate radiation call during the simulation. Consequently, the meteorology of the two experiments is identical.

The initial and boundary conditions of the mean monthly dust burden were acquired from a global simulation (CAM + EC-EARTH), for the decades 2000-2009 and 2010-2019. Therefore, a constant static map was used as boundary conditions for each month. A certain degree of error is expected at the boundaries of our domain that will not capture individual dust events or strong interannual variability. However, our analysis shows that the boundary forcing in the examined sub-regions is negligible in the dust annual cycle column burden of fine and coarse particles (Sect. 3.1). Because the aerosol lateral boundary conditions used a 4-bin dust model, we modified the boundary conditions for the 12-bin experiment. The new bins were defined according to the ratio between the 4- and 12-bin size range and size limits. Multiply- ing this ratio by each month and atmospheric level we have created the necessary global boundary condition for the 12bin dust scheme. This method assumes that the number of particles is homogeneously distributed in each bin.

The dust size range of the boundary conditions dataset spans $0.01-20 \mu \mathrm{m}$. Therefore, coarse dust size bins in both DUST4 and DUST12 scheme (e.g., that exceed the upper limit of the $20 \mu \mathrm{m}$ ) are not influenced by boundary conditions. This does not introduce a significant bias in our results since large particles $(>20 \mu \mathrm{m})$ have a short atmospheric lifetime and the main dust sources from outside the domain are located far from our simulation boundaries. The DUST12 experiment increased the computational cost by $66.8 \%$ in comparison to DUST4. However, we should note that the computational cost difference between the two experiments may vary under other model physics options and domain size.

\section{Results}

\subsection{Evaluation}

The four-bin simulation (DUST4) was evaluated against the climatological LIVAS DOD (Fig. 3). The high dust belt (DOD $>0.2$ ) between 15 and $25^{\circ} \mathrm{N}$ in RegCM4 generally matches the observed DOD of LIVAS with some spatial inconsistencies. We discuss these differences for key regions 
(a) Western Mediterranean

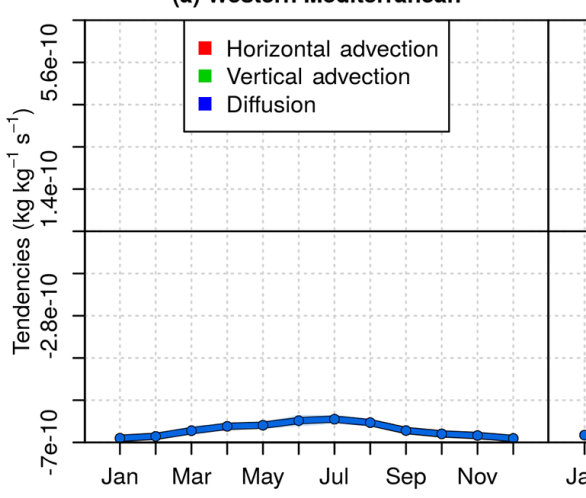

(d) Western Sahara (b) Central Mediterranean

Convective transport - Vertical turbulence Rainout (c) Eastern Mediterranean

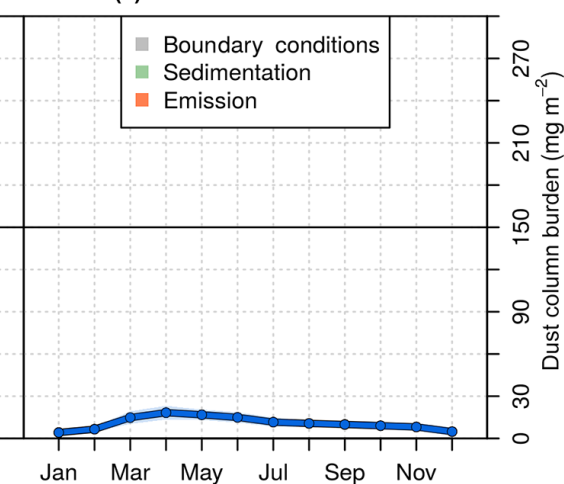

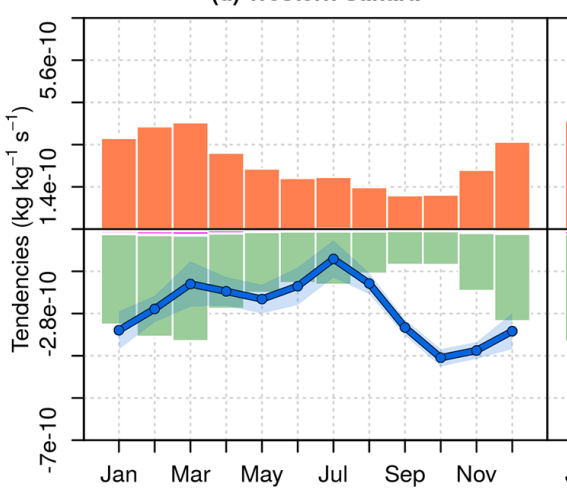

(e) Eastern Sahara

(f) Sahel

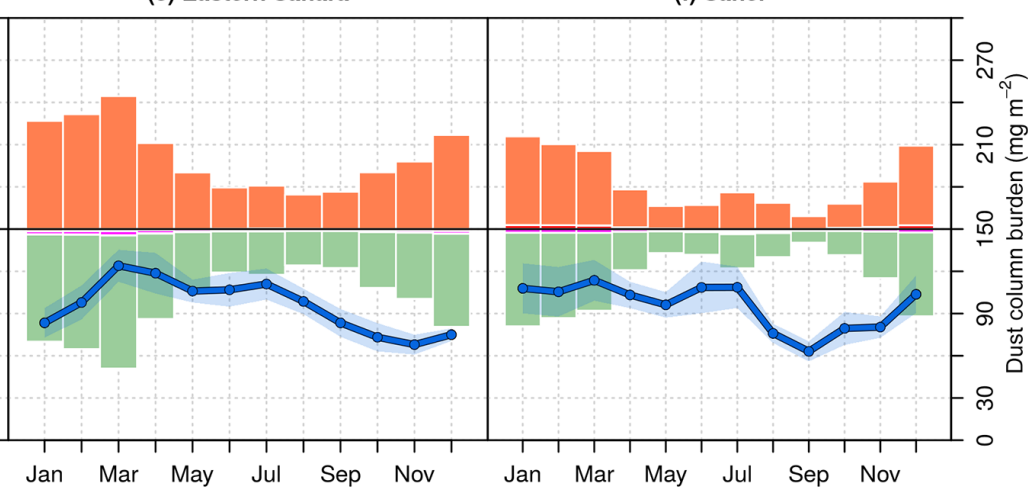

Figure 5. Coarse dust particle column burden of the DUST4 experiment (lines) alongside the production/destruction column tendencies (bars) averaged for the period December 2006 to November 2014. Shaded areas represent the $95 \%$ confidence interval of the mean.

Table 1. Simulation options implemented in RegCM4.

\begin{tabular}{ll}
\hline Grid dimensions & $140 \times 160,18 \sigma$ levels \\
\hline Horizontal resolution & $50 \mathrm{~km}$ \\
Top layer pressure & $50 \mathrm{hPa}$ \\
Meteorological boundary conditions & ERA-Interim (Dee et al., 2011) \\
Surface model & BATS (Dickinson et al., 1993) \\
Chemical boundary conditions & CAM + EC-EARTH \\
Cumulus convection scheme & Tiedtke (Tiedtke, 1989) \\
Transfer radiation scheme & CCM3 (Kiehl et al., 1996) \\
Moisture scheme & SUBEX (Pal et al., 2000) \\
Planetary boundary layer scheme & Modified Holtslag (Holtslag et al., 1990) \\
Dust tracers & DUST4 (4 bins, isolog) \\
& DUST12 (12 bins, isogradient; Foret et al., 2006) \\
Dust size particle distribution & Kok (Kok, 2011a) \\
\hline
\end{tabular}

(Fig. 2) according to the mean bias, the lower (LCI) and upper (UCI) $95 \%$ confidence intervals of the mean, and the percent bias (Pbias). RegCM4 underestimates DOD in a zone south of the Sahel around to $10^{\circ} \mathrm{N}$ by about 0.05 . Over the eastern Sahara (ESah), RegCM4 overestimates the climatological DOD by 0.083 (LCI: 0.078; UCI: 0.088; Pbias: $63.1 \%$ ), mainly in Chad and expanding to Libya, Egypt and northern Sudan. In the western Sahara (WSah), where the DOD is higher, the model mean overestimation is 0.043
(LCI: 0.039; UCI: 0.047; Pbias: 26.2\%). Over the Mediterranean, all grid points show a weak overestimation of DOD, which for the three Mediterranean regions combined is 0.027 (LCI: 0.026; UCI: 0.029; Pbias: 54.7\%).

Figure 4 shows the seasonal cycle of DOD in LIVAS observations and the DUST4 simulation for the six subregions depicted in Fig. 2. In the Mediterranean the observed monthly mean DOD values are typically less than 0.1 , with the RegCM4 maximum values reaching 0.15 in some months 
(Fig. 4a-c). Although there is an almost constant overestimation of DOD for all Mediterranean regions, the observed annual cycle maximum and minimum values are simulated adequately and we note that, generally, the monthly DOD values are relatively low. In the western Mediterranean DOD peaks in summer (Fig. 4a), while the eastern Mediterranean peak is in spring (Fig. 4c). Generally, the RegCM4 DUST4 simulation overestimates DOD with a secondary annual maximum in spring and summer over the western and eastern Mediterranean, respectively. The central Mediterranean is the transition area that receives dust throughout the year from transport paths that affect both the eastern and the western Mediterranean (Israelevich et al., 2012). Therefore, it exhibits a broad maximum that peaks mainly in spring and remains until late summer (Fig. 4b).

The spatial distribution of wet deposition, dry deposition and surface emission fluxes is depicted for the fine and coarse particles in Fig. S3. Over desert and semidesert areas, DOD values are higher and show greater intra-annual variability and amplitude in comparison to the Mediterranean subregions (Fig. 4d-f). The western Sahara DOD shows a strong summer maximum of 0.35 that is seven times higher than winter values (Fig. 4d). RegCM4 simulates accurately the mean monthly values in the first six months and overestimates in the summer and autumn by $0.03-0.07$. In the eastern Sahara, there is a significant overestimation of DOD during summer and autumn where the positive bias of the model is more than 0.1 in most months (Fig. 4e). The Sahel annual cycle is affected by the southward transport of dust from the Sahara and the seasonal movement of the Intertropical Convergence Zone (ITCZ; Ridley et al., 2012; Rodríguez et al., 2015). The local emission sources are activated mainly during winter (dry season) when soil moisture is low but DOD peaks in summer (Fig. 4f), indicating that the dust annual cycle is strongly affected by the inflow of dust from the Sahara into the Sahel. RegCM4 underestimates DOD during August-January and overestimates it during March-June (Fig. 4f).

To understand the simulated processes of dust productiondestruction-transport in the model and explain the discrepancies identified in the DOD annual cycle, we investigate the annual cycle of dust column burden for coarse-silt size (Dd $>2.5 \mu \mathrm{m}$, Fig. 5) and fine-clay size ( $\mathrm{Dd}<2.5 \mu \mathrm{m}$, Fig. 6) dust particles alongside the production/destruction column tendencies of dust. Fine particles dominate the annual cycle of the total column burden and control its seasonal variability, whereas coarse particles display a weak seasonal variability and its intra-annual amplitude is generally negligible in comparison to fine particles. The major tendencies that control the dust column burden in both fine and coarse particles is emission and sedimentation. Additionally, vertical turbulence as well as horizontal and vertical advection plays a considerable role in the desert regions for fine particles. The fine column burden annual cycle is anticorrelated with the absolute values of production/destruction tendencies in the desert; for example, during the warm season the absolute values of tendencies tend to be small and fine dust column burden high, with the opposite in the cold season. In most regions, fine and coarse particles peak during the same month, enhancing the total column burden seasonal variability (e.g., western Sahara, Sahel; Figs. 5e-f, 6e-f). However, in the eastern Sahara (Figs. 5d and 6d), fine and coarse annual cycles follow a completely different pattern. Coarse particles peak in spring, while fine particles exhibit a broad spring-summer maximum that peaks during late summer. This indicates that fine particles are responsible for the overestimation of DOD in the eastern Sahara as their burden and the size specific extinction coefficient (Fig. 1) is higher in comparison to the coarse dust particles.

Over the eastern and western Sahara both emission and sedimentation fluxes display a distinct spring maximum in March (Figs. 5d, e and 6d, e), which does not explain the annual cycles of dust column burden. The ratio of emission to dry deposition flux is connected to the dust column burden, rather than the absolute values of emission and dry deposition flux. Values greater than 1 demonstrate periods where the emission dominates in comparison to dry deposition rate, while values smaller than 1 show the dominance of deposition. Coarse particles, due to their low atmospheric lifetime, are deposited close to their source region and shortly after emission, therefore exhibiting a very low seasonal variability. Fine particles, on the other hand, remain in the atmosphere for longer and can travel over long distances, substantially affecting the emission to dry deposition ratio.

In the western Sahara the fine particle emission to deposition ratio for the full simulation period is 1.46 , which indicates that the model emits $46 \%$ more fine particles compared to its deposition. The coarse particle ratio is close to 1 . In the eastern Sahara the emission to deposition ratio is much higher than in the western Sahara, with values of 1.80 and 1.31 for fine and coarse particles, respectively. The strong and almost constant annual NNE and NNW winds in the region transports dust away from the source region increasing the dust outflow of the eastern Sahara (Fig. 7). Thus, deposition in the eastern Sahara decreases and the emission to deposition ratio rises. Furthermore, the fine particle emission to deposition ratio steadily increases from March to August, leading to an accumulation of fine dust particles in the atmosphere that increases the column burden and the DOD. In the Sahel throughout the year, emissions are 2 times greater than the deposition for fine particles, with a mean ratio of 2.26 . As discussed later, RegCM4 exhibits some biases in the total precipitation annual cycle that influences this ratio.

The column burden of dust can be affected by numerous meteorological variables that may alter the emission, deposition or the circulation and transport of dust. Thus, we have evaluated these variables with the observational gridded and reanalysis data to explain the spatial biases observed in the DOD. We chose the ERA-Interim for the evaluation of wind fields (surface, 925 and $850 \mathrm{hPa}$ ) in order to have large spa- 

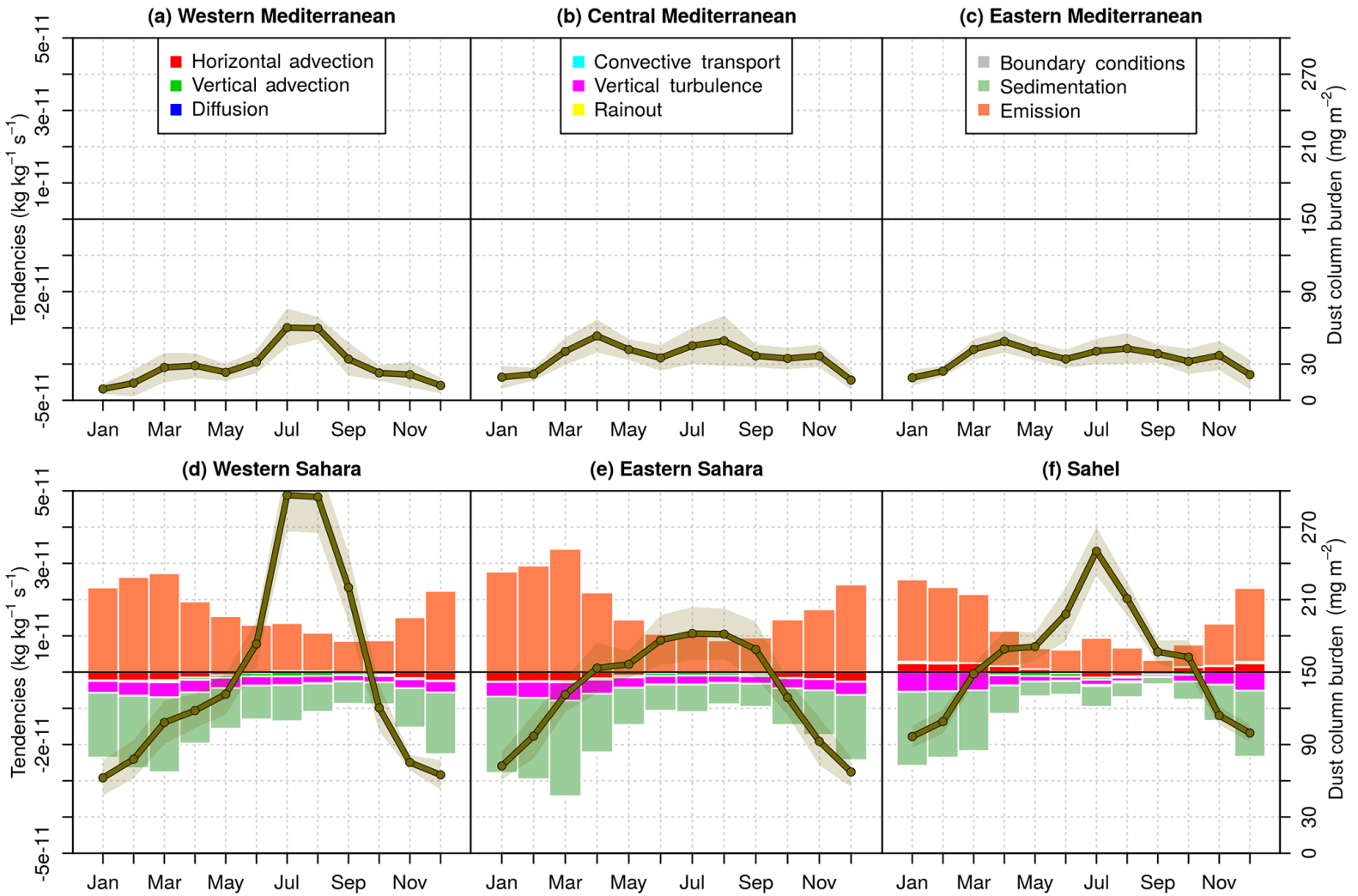

Figure 6. Fine dust particle column burden of the DUST4 experiment (lines) alongside production/destruction column tendencies (bars) averaged for the period December 2006 to November 2014. Shaded areas represent the $95 \%$ confidence interval of the mean.

(a) ERA-Interim, wind force $850 \mathrm{hPa}$

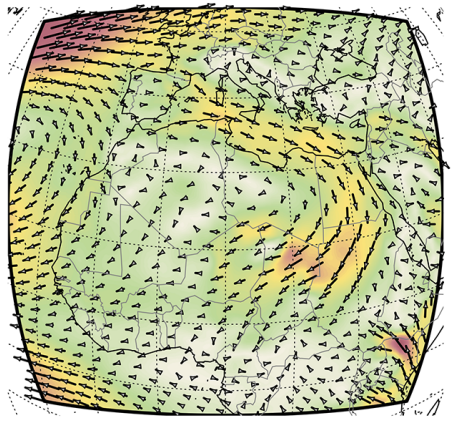

(b) DUST4, wind force $850 \mathrm{hPa}$

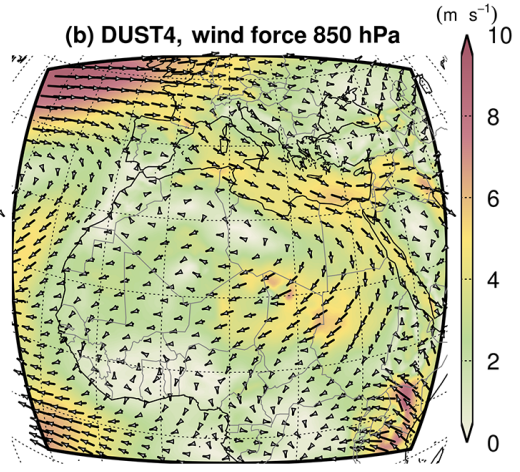

(c) DUST4-ERA-Interim

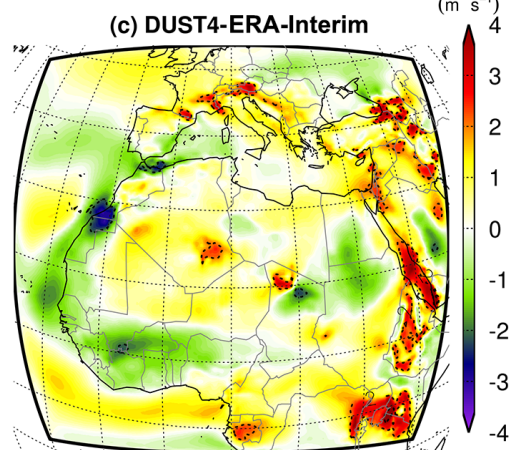

Figure 7. Wind velocity at $850 \mathrm{hPa}$ of the DUST4 experiment against the ERA-Interim reanalysis for the period December 2006 to November 2014.

tial coverage and a long-term, continuous availability of data. The surface wind velocity in RegCM, which constitutes the main driver of dust production through erosion, is comparable to ERA-Interim (Fig. S4). We observe some positive and negative biases over the desert that are generally less than $1 \mathrm{~m} \mathrm{~s}^{-1}$. Although the mean wind velocity is linked with dust emission, wind gustiness and dust emission fluxes exhibit higher temporal and spatial correlation (Engelstaedter and Washington, 2007). A wind gust is defined as a sudden increase in wind speed that lasts less than $20 \mathrm{~s}$. In our simulations, wind speed is calculated within the internal time step (120 s) of our model and wind gust is considered the maximum value of wind velocity within the last output time step (6 h). Typically, this calculation method is applied in most climate models and reanalysis products with different internal and output time steps. Therefore, it is difficult to draw conclusions when comparing the wind gust in RegCM and ERA-Interim, because the wind gust was calculated in differ- 


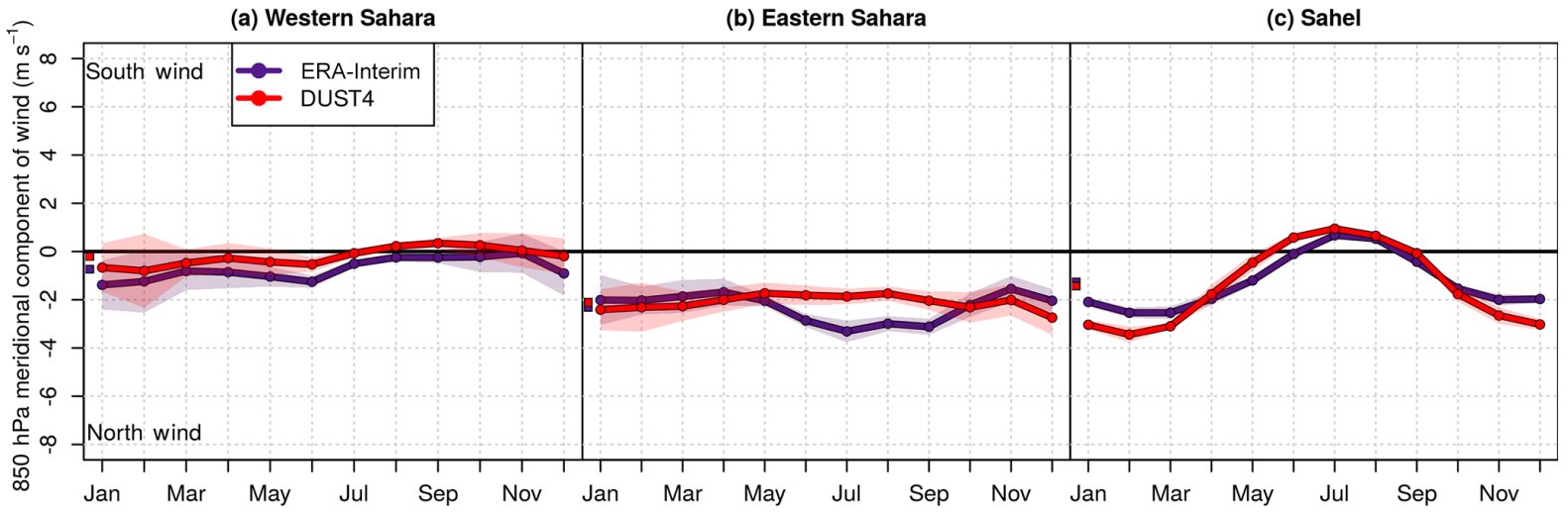

Figure 8. Annual cycle of the meridional wind component of ERA-Interim and DUST4 experiment for the period December 2006 to November 2014. Positive and negative values indicate south and north wind, respectively. Shaded areas represent the $95 \%$ confidence interval of the mean.

ent time frames. Alternatively, we calculated the mean field of the $6 \mathrm{~h}$ time steps that exceeded the 0.9 percentile value of wind velocity, averaged over the three desert subregions (eastern Sahara, western Sahara, Sahel; Fig. S5). The 0.9 percentile value of the averaged wind over the desert is 4.93 and $5.92 \mathrm{~m} \mathrm{~s}^{-1}$ for ERA-Interim and RegCM, respectively. RegCM clearly overestimates locally high wind velocity over the desert by $1-3 \mathrm{~m} \mathrm{~s}^{-1}$, which indicates that the model potentially overestimates dust emission flux.

In Egypt and northern Sudan, the strong surface NNE winds depicted in ERA-Interim are underestimated by RegCM, which may lower the simulated production of dust in the eastern Sahara. However, considering that the same wind pattern continues at both 925 and $850 \mathrm{hPa}$ and that the larger amount of dust is concentrated in these layers (Fig. 7), it can also decrease its southward transport and the outflow of dust in the eastern Sahara. In Fig. 8, the annual cycle of the meridional wind component confirms that, during the summer (June-September), the southward wind is underestimated by the model by more than $1 \mathrm{~m} \mathrm{~s}^{-1}$. Thus, a high load of dust remains stationary for a longer period over the eastern Sahara that likely increases the modeled column burden and the DOD (Fig. 4e).

Away from the Sahara region and especially in semiarid environments, like the Sahel, precipitation can affect both emission and wet deposition processes. According to the CRU database, RegCM overestimates precipitation in the Sahel by $10-20 \mathrm{~mm} \mathrm{month}^{-1}$ (Fig. S6), which increases wet deposition as well as soil moisture and vegetation (Engelstaedter et al., 2006). Consequently, more dust is deposited and less is emitted. According to the annual cycle of total precipitation (Fig. 9) the overestimation of precipitation during April, May and June probably contributes to the underestimation of DOD (Fig. 4f). The same process prevents the southward transport of dust to lower latitudes and is partly responsible for the strong underestimation of DOD close to the Gulf of Guinea.
The vertical distribution of dust is evaluated for the six subregions for vertical tendencies (advection, convective transport, vertical turbulence and sedimentation) in Fig. 10. The first $200 \mathrm{~m}$ of dust extinction (DEX) values were excluded from the analysis due to measurement restriction of LIVAS. The tendencies are illustrated in the plot as percentages for the layers $0.2-5$ and $5-10 \mathrm{~km}$. DEX is overestimated by $\mathrm{RegCM}$ in all subregions in the middle and upper troposphere. More than $95 \%$ of dust is located in the first $5 \mathrm{~km}$ from the surface according to DEX measurements from LIVAS. However, RegCM places more dust at higher altitudes, with only $80-90 \%$ located between 0 and $5 \mathrm{~km}$. In the western Sahara and Sahel, DEX is underestimated by RegCM until the height of $5 \mathrm{~km}$ (Fig. 10d and f) and above that height there is a constant positive bias that decreases with altitude. The large observed DEX values between 3 and $5 \mathrm{~km}$ over the Sahel indicates the high amount of fine dust particles that reach higher altitudes as compared to the eastern and western Sahara. In the eastern Sahara the DEX is overestimated between 3 and $13 \mathrm{~km}$. In the western, central and eastern Mediterranean regions, the DEX is overestimated above about $2-3 \mathrm{~km}$ and underestimated below this height (Fig. 10a-c).

In the model, the vertical transport of dust is controlled by four main processes: sedimentation, vertical turbulence, vertical advection and convective transport. The sedimentation tendency is always negative and equally important in all heights, whereas vertical turbulence plays a major role in the first few kilometers of the atmosphere and vertical advection and convective transport, prevail at higher altitudes. As shown in Fig. 10, in the first $5 \mathrm{~km}$ of the atmosphere, sedimentation exhibits negative values (contribution $>-40 \%$ ), which removes dust from the atmosphere. On the other hand, vertical turbulence is the main force that raises dust upwards (contribution $>50 \%$ ). The planetary boundary layer (PBL) scheme based on Holtslag et al. (1990) produces high vertical turbulence in the first couple of kilometers in the at- 
(a) Western Mediterranean

(b) Central Mediterranean

(c) Eastern Mediterranean

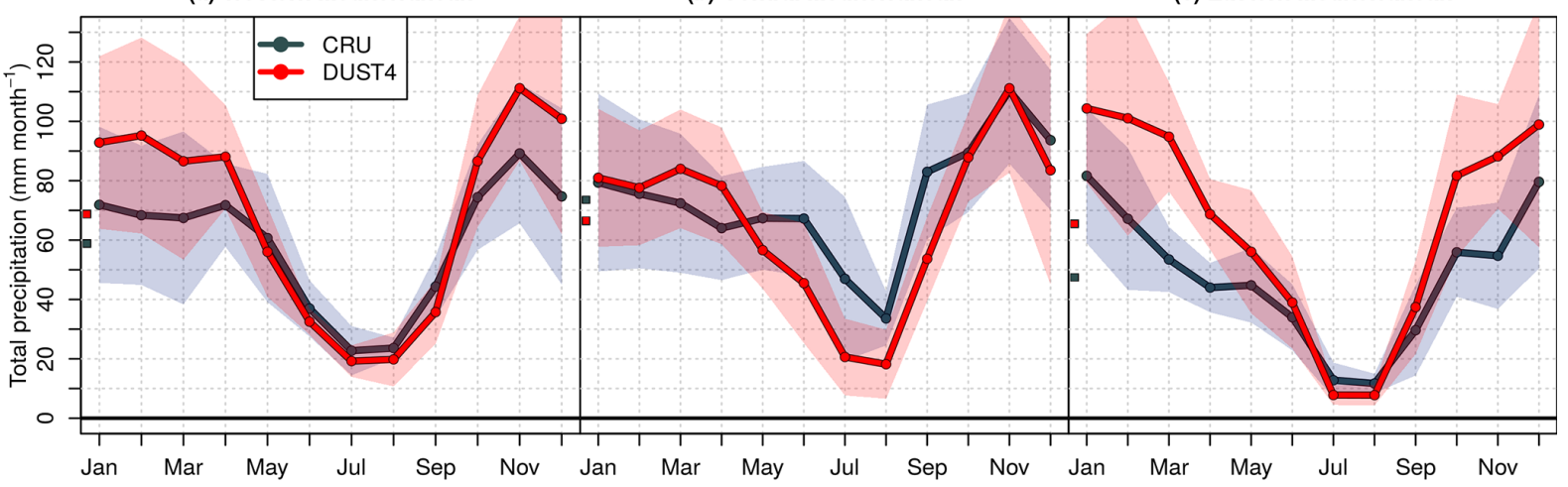

(d) Western Sahara

(e) Eastern Sahara

(f) Sahel

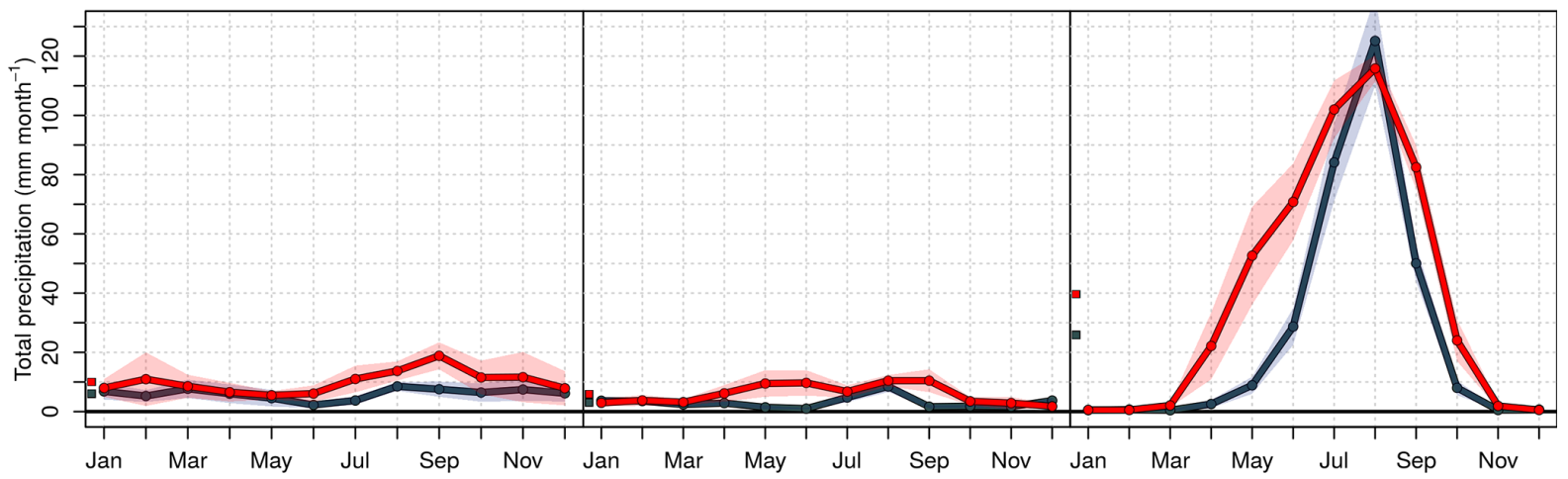

Figure 9. Total precipitation annual cycle of the ERA-Interim and DUST4 experiment for the period December 2006 to November 2014.

mosphere, and this may contribute to the underestimation or overestimation of the modeled DEX profile as compared to LIVAS measurements. We have simulated 2008 with the alternative PBL scheme option in RegCM4 based on Bretherton et al. (2004), which suggests an improvement as far as the vertical distribution of dust in the PBL, although column DOD and DEX bias increases, especially over the eastern Sahara (Fig. S7). The vertical advection and more importantly convective transport between 5 and $10 \mathrm{~km}$ show positive values on average, which causes dust to be transported upward. Over the Mediterranean region, vertical advection (>20\%) and convective transport ( $>30 \%$ ) contribution is equally important (Fig. 10a-c), while in the Sahara and Sahel convective transport is the most significant factor ( $>65 \%$; Fig. 10df). The overestimated DEX profile in this altitude range suggests that the cumulus convection activity/convective transport mechanism is overactive in the Tiedtke scheme (Tiedtke, 1989) or another negative sign process (e.g., sedimentation) is not properly represented by the model. Discrepancies in the vertical distribution of dust can also be misinterpreted from possible local emission errors, the lack of simulated vertical levels or wet deposition biases. Further research is needed in this regard to reduce the mean vertical distribution bias of dust in the model.

The model was also evaluated in terms of the surface net downward shortwave and net upward longwave radiation flux against CERES satellite measurements (Fig. S8). In the shortwave spectrum, the radiation flux bias ranges between -10 and $10 \mathrm{~W} \mathrm{~m}^{-2}$ above the desert and the Mediterranean, while in the longwave the differences are mostly positive $\left(\sim 10 \mathrm{~W} \mathrm{~m}^{-2}\right)$.

\subsection{Comparison of 4-bin and 12-bin experiments}

The optical properties for the 4- and 12-dust-size bin simulations were calculated using a Mie scattering code for each CCM3 radiation band. As noted above, the meteorological forcing between the two models is the same; therefore, the emission fluxes which depend on the model's resolvable winds remain the same. Thus, the changes in column burden between the two experiments can only emerge from the new dust size discretization that theoretically improves dust transport and dry deposition processes, and the changes in DOD can only be attributed to changes related to transport and deposition.

Figure 11 compares the DOD coarse and fine column burden between the DUST4 and DUST12 for the full simulation period. The DOD percent increase is between 10.4 and $13 \%$ for all the subregions. Furthermore, there is a distinctive increase by 0.04 with the 12-bin model over the Sahara and especially along the Sahel region, where the DOD values are higher (Fig. 11c). In comparison with the DUST4 simula- 


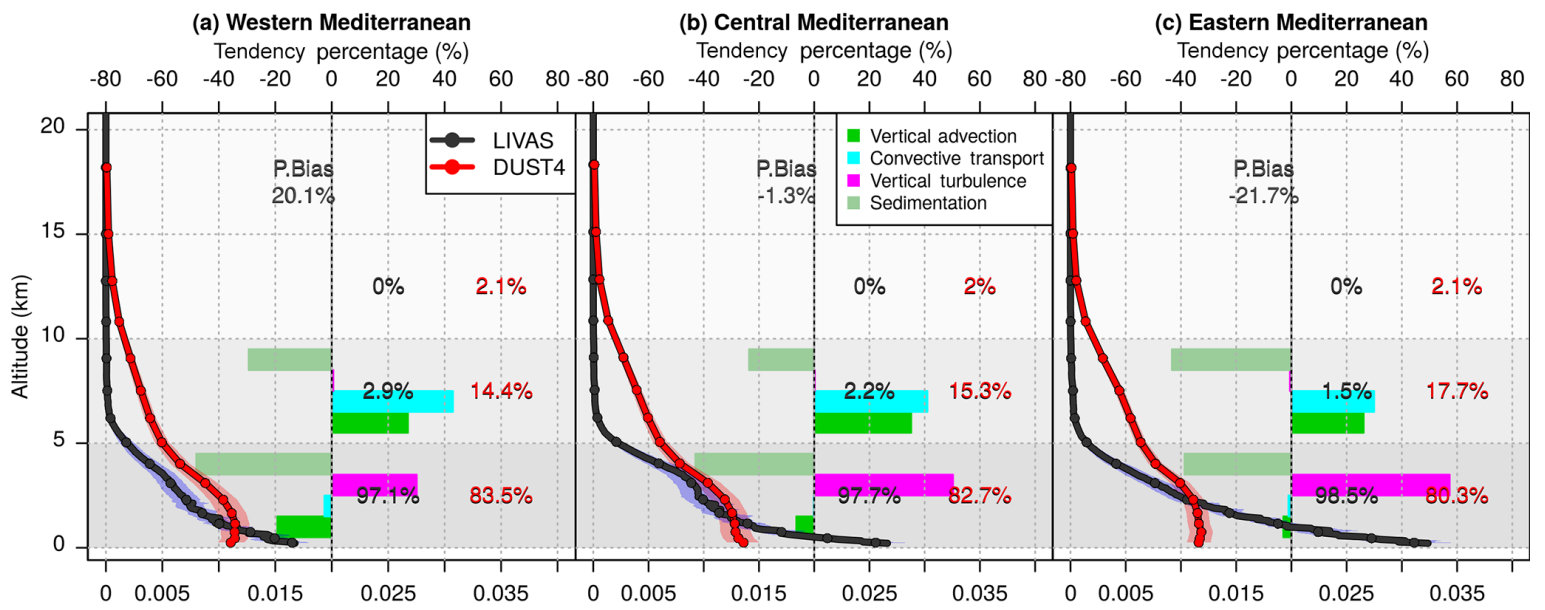

(d) Western Sahara

(e) Eastern Sahara

(f) Sahel

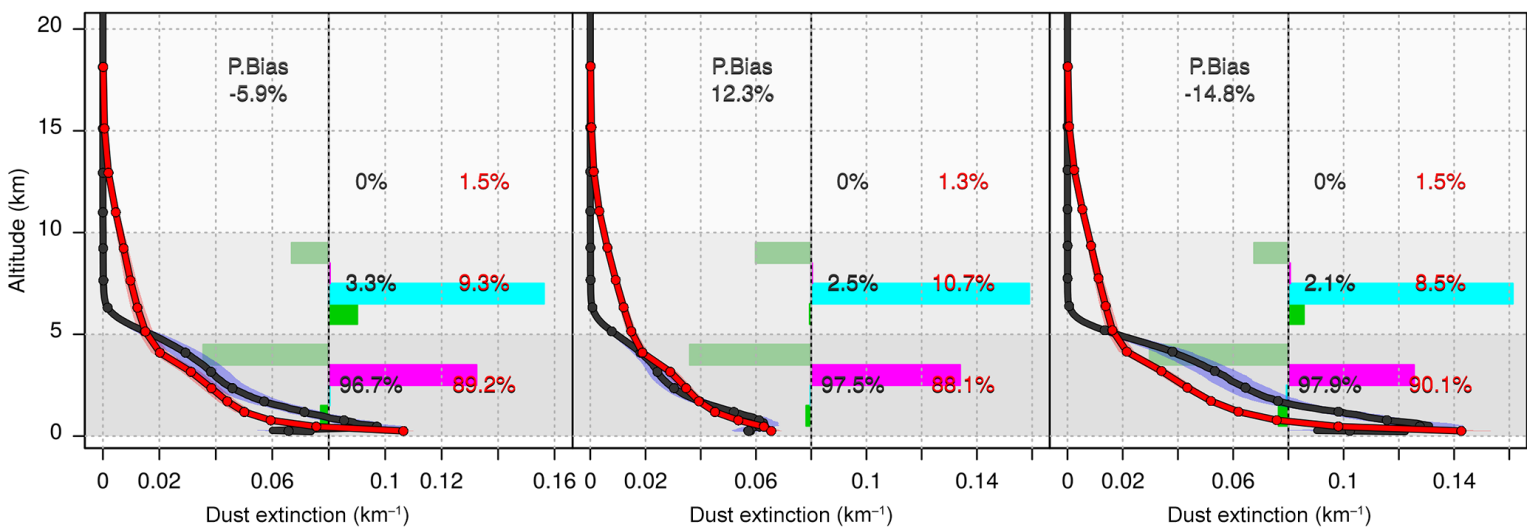

Figure 10. Dust extinction profiles of LIVAS and the DUST4 experiment. The percent bias (P.Bias) of dust extinction between 0.2 and 5,5 and 10 , and 10 and $20 \mathrm{~km}$ for each subregion is illustrated on the plots. The bars depict the percent of the vertical tendencies for $0.2-5$ and $5-10 \mathrm{~km}$.

tion the DUST12 simulation increases the deposition lifetime (column burden/total deposition flux) by $3.5 \mathrm{~h}$ and $2 \mathrm{~min}$ for fine and coarse particles, respectively. Consequently, this increases the dust column burden of fine $(+4 \%)$ and coarse $(+3 \%)$ particles (Fig. 11f, i). The changes in the fine particles correlates better with the changes in DOD, because dust extinction coefficient is much higher for fine particles $(<2.5 \mu \mathrm{m}$; Fig. 1). Over the Middle East and the northern part of the Arabian Peninsula we observe a distinct increase in the coarse dust column burden by $10 \mathrm{mg} \mathrm{m}^{-2}$. The differences of DOD and column burden between the two experiments, calculated from the monthly data for each grid, are statistically significant at the $95 \%$ confidence level according to a two-tailed paired $t$ test for almost all the grid points of the simulated domain.

The dust bin resolution also depends on the emission size distribution considered for the dust. In our study we use the Kok (2011a) dust PSD, which, as already mentioned, improves the DOD and the seasonality over the Sahara region (Nabat et al., 2012). However, Kok (2011a) PSD drops very fast for large and small dust particles. Other typical dust size distributions (e.g., Alfaro et al., 1998; Zender, 2003) do not show such a sharp drop when increasing or decreasing the dust particle diameter (Kok, 2011a); thus, they could be much more sensitive to the binning partitioning method and number, which will generate larger changes in dust column burden and DOD.

Figure 12 shows the annual cycle of DOD for LIVAS, DUST4 and DUST 12 experiments. The monthly differences of the two experiments against LIVAS can be found in Fig. S9. In all regions, the DUST12 experiment increases the DOD in comparison to DUST4. This is attributed to the increase in lifetime in fine and coarse dust particles in DUST12 with respect to DUST4 as also discussed earlier. Previous studies (Foret et al., 2006; Menut et al., 2007) revealed that the new approach in dust size bin partitioning and number (which is also adopted in our DUST12 experiment) more realistically simulates the transport and dry deposition of the dust size bins. This does not imply that the simulated biases will be reduced for all regions in the DUST12 experiment. The major factor that controls and potentially creates the first order biases in dust models is the balance between the emis- 

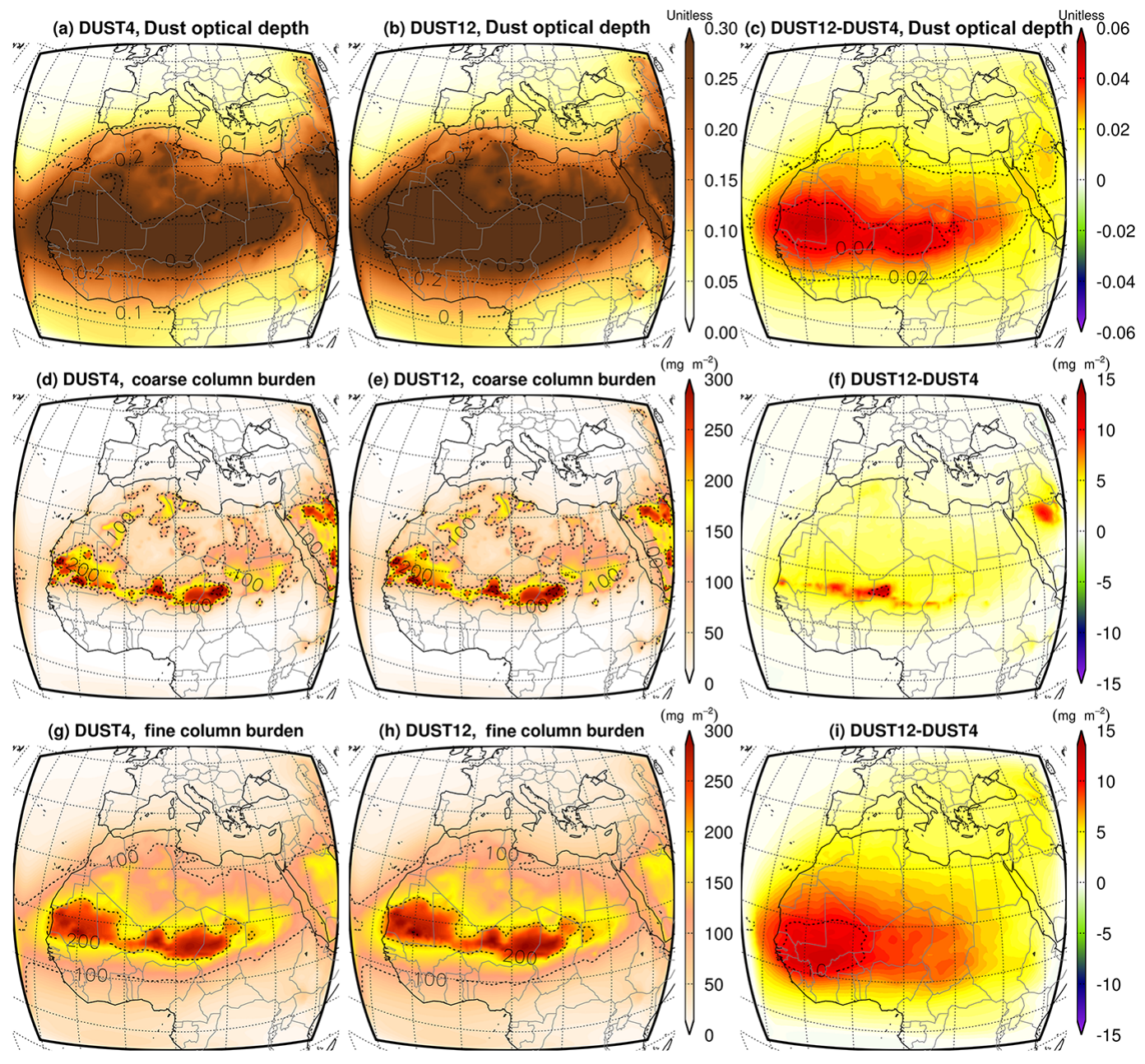

Figure 11. Dust optical depth and coarse $(>2.5 \mu \mathrm{m})$ and fine $(<2.5 \mu \mathrm{m})$ column burden of DUST4 and DUST12 experiments for the period December 2006 to November 2014.

sion and sedimentation terms (e.g., Figs. 5, 6). As discussed in Sect. 3.1, some positive DOD biases (e.g., eastern Sahara) might be due to an underestimation of the outflow of dust or a local overestimation of the emission flux from surface wind velocity errors. Therefore, although the new dust size parameterization theoretically improves dry deposition, it does not necessarily regulate or improve the biases that originate from other processes.

\subsection{Radiative forcing $(\mathbf{R F})$}

Dust particles can interact with both the shortwave and the longwave radiation, creating a dimming or a heating radiative effect on climate (Liao and Seinfeld, 1998). Some of these processes are illustrated for the shortwave spectrum in Fig. S10. According to the model the radiation forcing over the Sahel and the North Atlantic ocean is greater than $-5 \mathrm{~W} \mathrm{~m}^{-2}$ (Fig. 13a, b). The albedo in the desert areas is already very high, and in most cases surface albedo does not change from the suspended dust. However, close to the high emission dust source of Bodélé Depression we can observe positive RF values. In the model dust aloft decreases the already high albedo of the desert and creates a positive $\mathrm{RF}$ at the top of the atmosphere (TOA). In the Bodélé Depression, sediments were deposited during the Holocene in the bed of the Mega-Chad paleolake and the large diatomite sediments formed there have high albedo values that are visible in satellite images (Bristow et al., 2010). It is interesting that RegCM4 simulates a positive radiative response caused by the combination of high surface albedo values and high emission fluxes on that area, and the change to DUST12 decreases this positive response (Fig. 13c). The DUST12 experiment enhances the negative radiative forcing in the central and eastern Mediterranean by $-0.24 \mathrm{~W} \mathrm{~m}^{-2}(10.5 \%)$ and in the eastern Mediterranean by $-0.18 \mathrm{~W} \mathrm{~m}^{-2}(8.7 \%)$. The highest absolute changes are located over the Sahel, where the negative radiative forcing strengthens by $-0.41 \mathrm{~W} \mathrm{~m}^{-2}$ $(12.1 \%)$. 
(a) Western Mediterranean

(b) Central Mediterranean

(c) Eastern Mediterranean

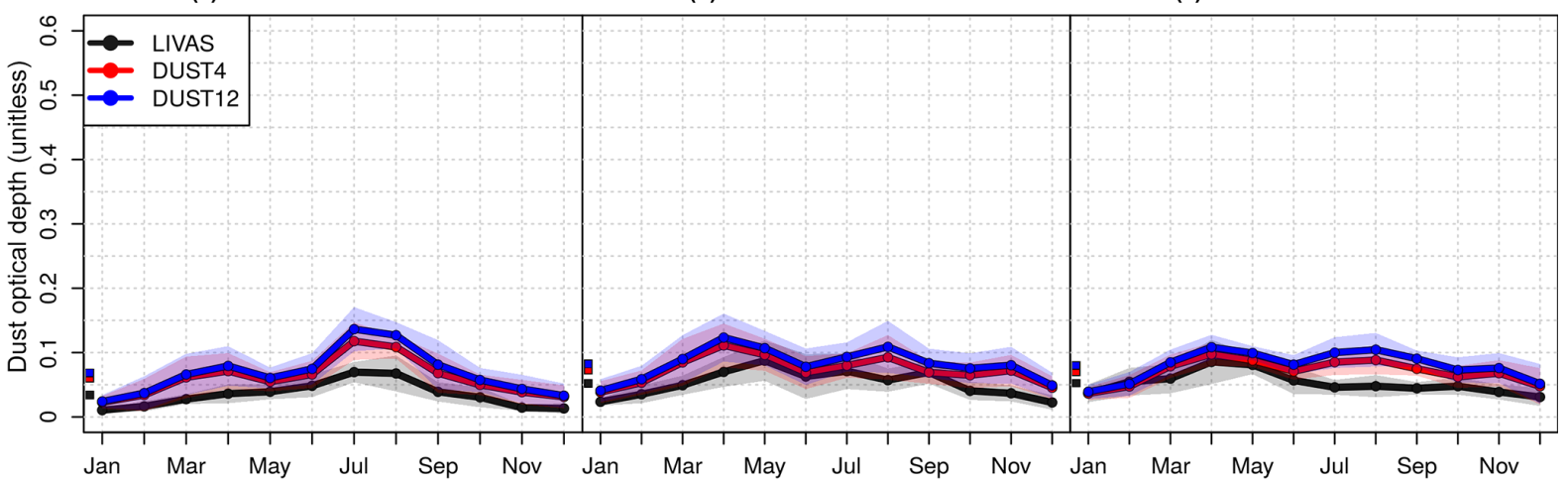

(d) Western Sahara

(e) Eastern Sahara

(f) Sahel

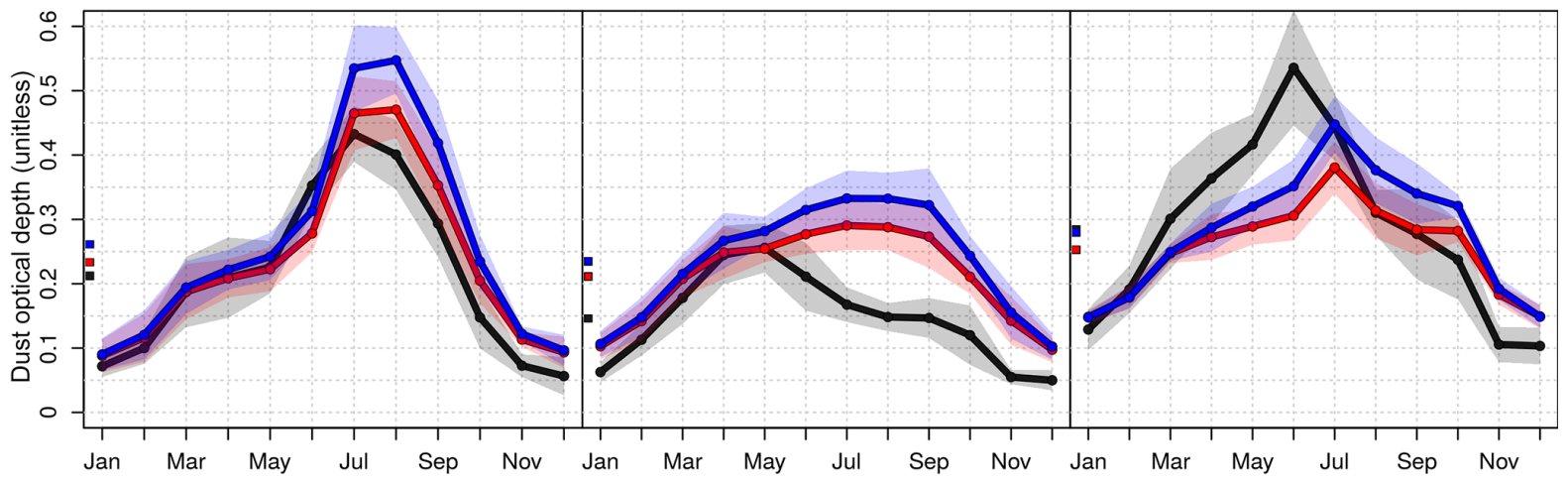

Figure 12. Annual cycle of dust optical depth of LIVAS, DUST4 and DUST12 experiments for the period December 2006 to November 2014.

The radiative process that backscatters and reflects the incoming solar radiation is the dominant global mechanism that affects climate. As shown in Fig. 13d and e, dust prevents more than $20 \mathrm{~W} \mathrm{~m}^{-2}$ of incoming solar radiation from reaching the surface on the desert and $5-10 \mathrm{~W} \mathrm{~m}^{-2}$ on the Mediterranean. The highest absolute differences between the two experiments are located on the western part of Africa between 15 and $20^{\circ} \mathrm{N}$, where the highest fine dust burden differences between DUST4 and DUST12 were noted (Fig. 11i). These negative changes are located in the region with the most persistent dust concentrations (Fig. $11 \mathrm{~g}, \mathrm{~h}$ ) and changes in the dust size bins might have a bigger effect over the longrange transatlantic transport than local forcing. It is worth discussing the source of the surface positive radiative forcing differences between the DUST12 and DUST4 experiment (Fig. 13f), which is related to the TOA discussion. The positive RF at the TOA over the Bodélé Depression is reduced in the DUST12 experiment, allowing less downward shortwave radiation to reach the surface. Consequently, there is less available downward radiation to be scattered and reflected on these areas, and the negative radiative forcing in DUST12 is smaller than DUST4. As a result the difference (DUST12-DUST4) is positive. The simulated shortwave radiative forcing by the four-bin isolog method is to some extent numerically efficient and acceptable. Nevertheless, our work emphasizes that the simplified representation of the four-bin approach underestimates the direct radiative forcing of dust by $13.7 \%\left(-0.29 \mathrm{~W} \mathrm{~m}^{-2}\right)$ and the shortwave surface (SRF) radiative forcing by $1.8 \%\left(-0.23 \mathrm{~W} \mathrm{~m}^{-2}\right)$.

In the longwave spectrum, the RF is always positive. Coarse dust particles in the atmosphere absorb the upward longwave radiation from the Earth and re-emit it either towards the surface or upwards to space. A part of the Earth's longwave radiation is absorbed by dust and limits the portion of upward longwave radiation that reaches the TOA, making the RF positive (Fig. 14a, b). A fraction of the absorbed longwave radiation is re-emitted back towards the Earth and increases the downward longwave radiation on the surface, creating a positive RF (Fig. 14d, e). In both cases the DUST12 experiment enhances the positive RF by $0.1 \mathrm{~W} \mathrm{~m}^{-2}$ in a large portion over the Sahara, the northern part of the Arabian Peninsula and the Middle East (Fig. 14c, f). More specifically, at the TOA, the positive radiative forcing enhances over the eastern and western Sahara by 0.08 $(6.9 \%)$ and $0.07 \mathrm{~W} \mathrm{~m}^{-2}(5.9 \%)$, while in the western, central and eastern Mediterranean it increases by 0.02 (7.8\%), 0.03 (7.8\%) and $0.04 \mathrm{~W} \mathrm{~m}^{-2}$ (8.3\%; Fig. 14c). Similarly, at the surface the positive radiative forcing rise by $0.08(3.0 \%)$ and $0.09 \mathrm{~W} \mathrm{~m}^{-2}(2.7 \%)$ in the eastern and western Sahara and $0.9(6.3 \%), 0.08(4.8 \%)$ and $0.9 \mathrm{~W} \mathrm{~m}^{-2}(6.5 \%)$ in the west- 

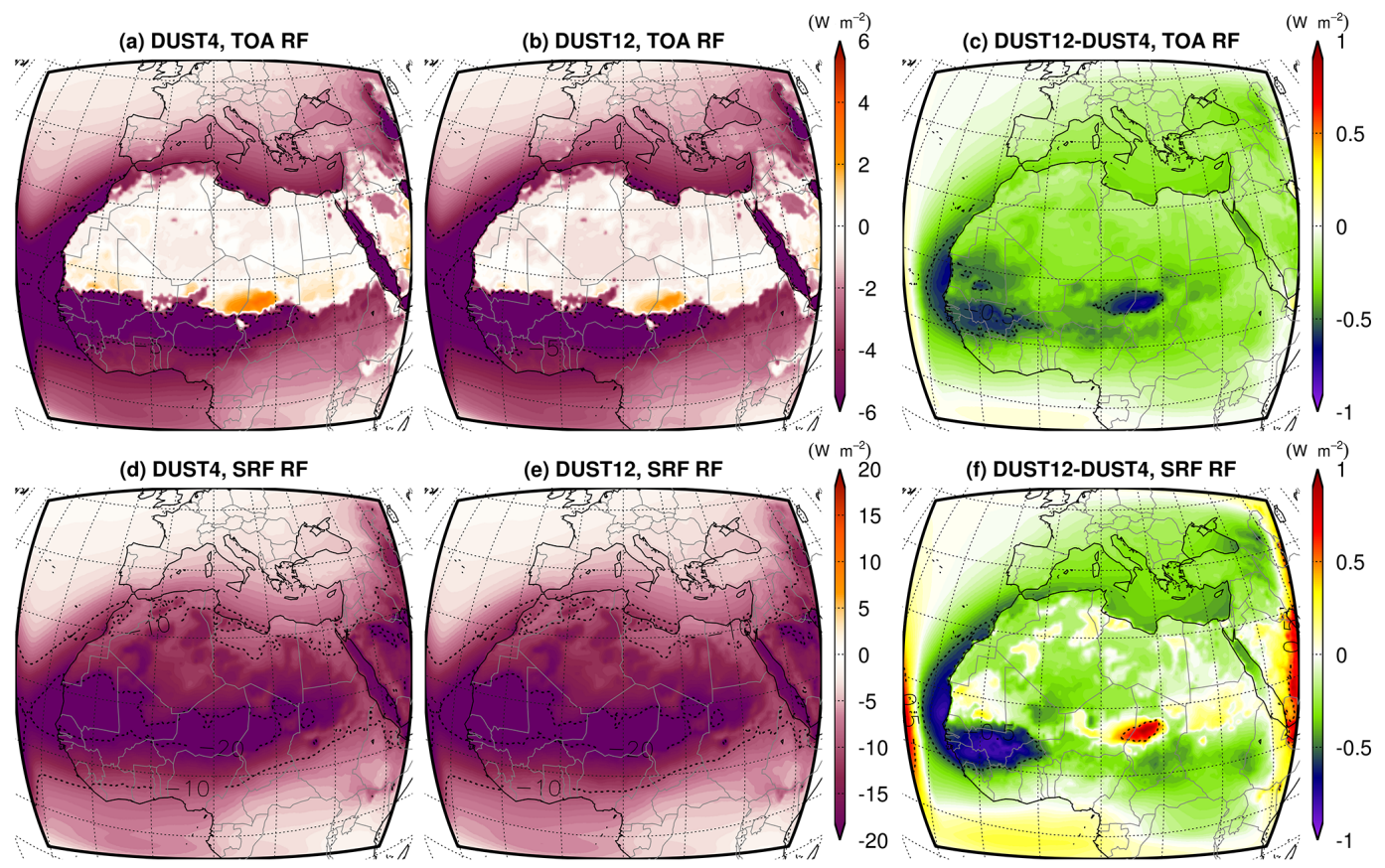

Figure 13. Top-of-the-atmosphere (top) and surface (bottom) radiative forcing in the shortwave spectrum for the period December 2006 to November 2014.

ern, central and eastern Mediterranean (Fig. 14f). The shortwave and longwave radiative forcing differences between the two experiment, calculated from the monthly data for each grid, are statistically significant at the $95 \%$ confidence level according to a two-tailed paired $t$ test for almost all the grid points of the simulated domain.

However, the current treatment of the optical properties of dust in the longwave spectrum of CCM3 scheme is limited and does not account for specific absorption coefficient for each dust size bin. Furthermore, the CCM3 longwave bands are concentrated on the absorption of $\mathrm{H}_{2} \mathrm{O}$ and $\mathrm{CO}_{2}$ and they do not integrate in detail the absorbing aerosol component part of the longwave. Therefore, we have conducted two similar dust experiments for June 2008 using the radiation transfer scheme RRTM, which is known for its detailed longwave calculation. We note again that the current version of RRTM (+McICA) produces randomly generated noise on radiation fields; therefore, the dust emission fluxes are not identical between the DUST4 and DUST12 experiments. Our preliminary simulations using the RRTM scheme (Fig. S12) have shown notably lower longwave dust RF over the desert in comparison to CCM3 (Fig. S11) for the same period and roughly the same DOD levels and spatial patterns. More specifically, the DOD and the longwave radiative forcing averaged above the Sahara for the CCM3_DUST4 experiment is $\mathrm{DOD}=0.31, \mathrm{SRF}=3.5$ and $\mathrm{TOA}=2.1 \mathrm{~W} \mathrm{~m}^{-2}$, while the related values for the RRTM_DUST4 experiment are DOD = $0.29, \mathrm{SRF}=1.9$ and $\mathrm{TOA}=0.6 \mathrm{~W} \mathrm{~m}^{-2}$. Although DOD increases in the 12-bin experiment in both radiation schemes
(Figs. S11c, S12c), the longwave RF changes display a striking difference. With the CCM3 radiation scheme, the longwave radiation linearly increases with higher DOD and dust burden values (Fig. S11f and i). In comparison, the RRTM scheme uses a specific absorption coefficient for each dust size bin, taking into account the fine/coarse dust burden changes. Thus, it exhibits local increases or decreases in the longwave RF (Fig. S12f and i), according to the changes of fine to coarse dust burden. Overall, the total longwave RF increase in RRTM is smaller compared to CCM3 when spatially averaged over the Sahara.

\section{Conclusions}

In the present study, we investigate the role of the modeled particle size distribution on DOD, total column burden and radiative forcing of dust in a regional climate model. We evaluate the regional climate model RegCM4 dust optical depth and dust extinction with the LIVAS dust product to understand potential model biases and link these with size-dependent emission and atmospheric processes. Generally, RegCM4 overestimates dust optical depth over important source regions such as the eastern and western Sahara by 0.083 (Pbias: $63.1 \%$ ) and 0.043 (Pbias: 26.2\%), respectively, and in the Mediterranean by 0.027 (Pbias: $54.7 \%$ ).

The dust optical depth annual cycle of LIVAS adequately correlates with RegCM4 in most regions. In the western Mediterranean, RegCM shows an annual cycle with a summer maximum similar to LIVAS, and in the eastern Mediter- 


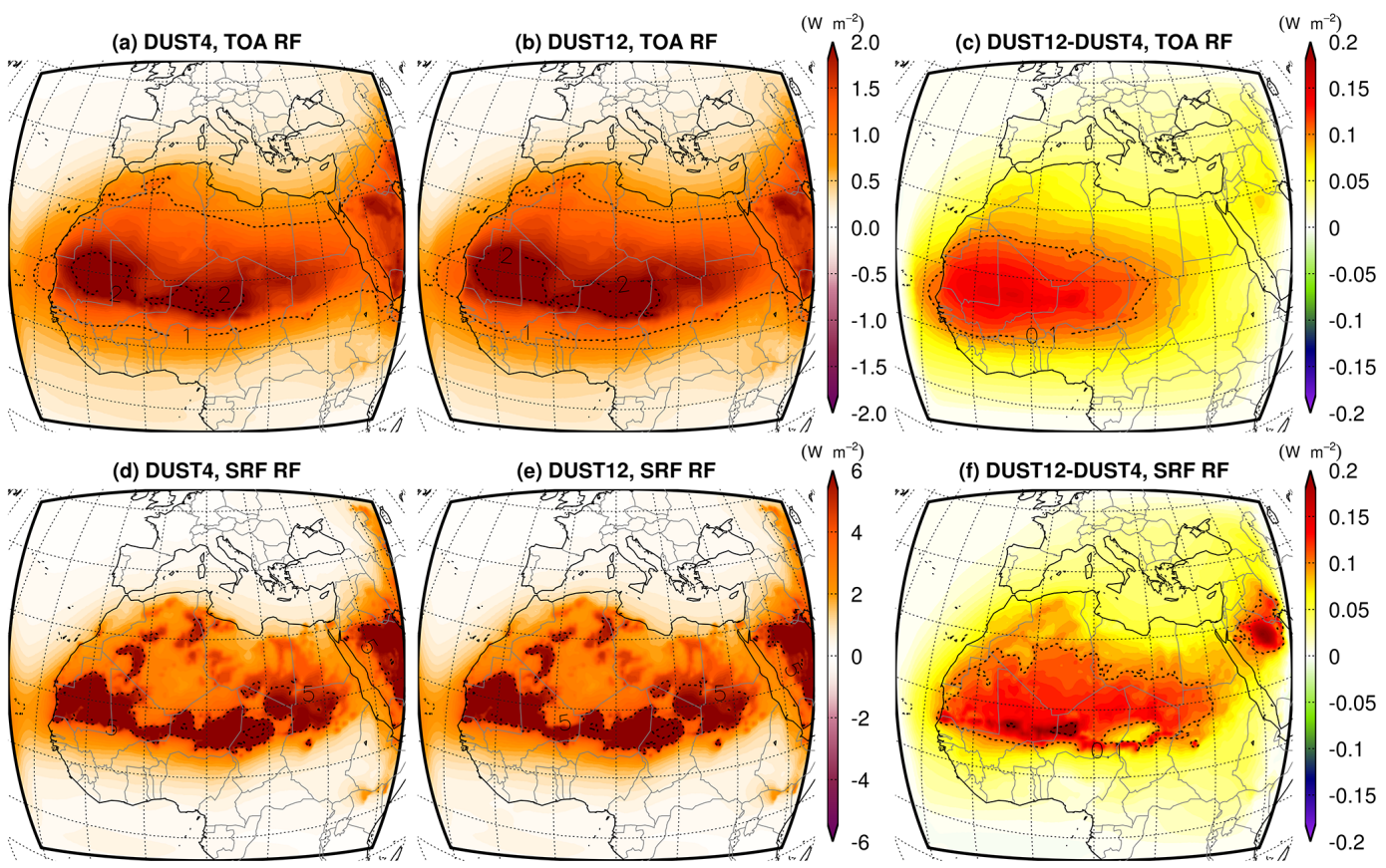

Figure 14. Top-of-the-atmosphere (top) and surface (bottom) radiative forcing in the longwave spectrum for the period December 2006 to November 2014.

ranean RegCM captures the spring maximum observed in LIVAS but additionally illustrates a secondary maximum in summer. In the western Sahara, the RegCM DOD annual cycle correlates with LIVAS, although there is a constant overestimation during summer and autumn while in the eastern Sahara RegCM shows a broad spring-summer maximum, while the observations show a clear spring maximum. In the Sahel, the model captures the observed DOD summer maximum.

We then evaluate the modeled emission and sedimentation terms, as these are the most important factors for the production and deposition of dust. Additionally, vertical turbulence, horizontal and vertical advection show a considerable negative tendency for the fine dust particles ( $\mathrm{Dd}<2.5 \mu \mathrm{m}$ ). According to the annual cycle of the meridional wind component in ERA-Interim, the model underestimates the southward wind in the eastern Sahara and probably decreases the outflow of dust in the area. Furthermore, the 0.9 percentile value of the averaged wind over the desert is 4.93 and $5.92 \mathrm{~m} \mathrm{~s}^{-1}$ for RegCM and ERA-Interim, respectively, which indicates that the model potentially overestimates dust emission flux. In the Sahel during April, May and June the total precipitation is overestimated by the model in comparison with the CRU database. Thus, wet deposition is enhanced and the emission flux is decreased since the ground has higher moisture. Overall, this process-level analysis suggests that meteorological drivers such as wind and precipitation may explain some model biases with observations.
These changes in the physical processes then link to the radiative properties that affect climate. We evaluate the dust extinction (DEX) from the model with LIVAS observations, and find that the RegCM overestimates DEX in all subregions in the middle and upper troposphere, which can be attributed either to an overestimation of dust convective transport or to an underestimation of some other deposition process (e.g., sedimentation). In the western Sahara and Sahel, DEX is underestimated by RegCM below $5 \mathrm{~km}$, suggesting that the emissions and deposition processes are not well balanced in the model. Our 1-year sensitivity study showed that the PBL mixing scheme (e.g., changing from Holtslag et al., 1990, to Bretherton et al., 2004) can potentially improve the dust vertical distribution in the boundary layer by reducing overactive mixing.

The effect of the two different approaches on the number and the partitioning method of dust size bins was investigated in the model with two experiments: a 4-size bin simulation based on the isolog approach (DUST4) and a 12-size bin simulation based on the isogradient approach (DUST12). The DUST12 experiment increases the deposition lifetime by $3.5 \mathrm{~h}$ and $2 \mathrm{~min}$ for fine and coarse particles, respectively, in comparison to DUST4. Consequently, the dust column burden increases by $4 \%$ (fine) and $3 \%$ (coarse), which boosts DOD by approximately $10 \%$ over the desert and the Mediterranean.

The negative surface radiative forcing of DUST12 experiment in the shortwave spectrum is regionally enhanced by $-0.5 \mathrm{~W} \mathrm{~m}^{-2}$, while the TOA radiative forcing is intensified 
by almost $-1 \mathrm{~W} \mathrm{~m}^{-2}(10 \%)$. The negative changes in the surface radiative forcing are concentrated in the western part of Africa and extend over the eastern Atlantic, where the near-constant annual dust plume is located. In the longwave spectrum DUST12 experiment enhances the positive RF at the surface and TOA by $0.1 \mathrm{~W} \mathrm{~m}^{-2}$ ( 3 and $7 \%$, respectively) in a large portion of the Sahara, the northern part of the Arabian Peninsula and the middle east. Although the radiation transfer scheme RRTM, known for its detailed integration in the longwave spectrum, revealed that these longwave RF changes can be also locally negative and therefore smaller when spatially averaged over the Sahara.

Overall, this study highlights that the DOD, dust column burden and radiative forcing differences between the two dust size bin treatments are relatively small. The 12-bin isogradient method more realistically represents the physical processes such as deposition and optical properties of dust; nevertheless, the 4-bin isolog method is numerically efficient and can be useful for long-term regional climate simulations. We should note that other typical size distributions (e.g., Alfaro et al., 1998; Zender et al., 2003) could be much more sensitive to the binning partitioning method and number, which will generate larger changes in dust column burden DOD and RF.

\section{Data availability}

ERA-Interim wind velocity data are publicly available from the ECMWF and can be downloaded from http://www.ecmwf.int/en/research/climate-reanalysis/ era-interim. CRU TS 3.23 precipitation data can be obtained from https://crudata.uea.ac.uk/cru/data/hrg/cru ts_3.23/cruts.1506241137.v3.23/. The LIVAS database is available at http://lidar.space.noa.gr:8080/livas/. The regional climate model ReGCM4 code is available at https://gforge.ictp.it/gf/project/regcm/frs/. RegCM4 simulation data are available upon request from Athanasios Tsikerdekis (tsike@geo.auth.gr).

\section{The Supplement related to this article is available online at doi:10.5194/acp-17-769-2017-supplement.}

Acknowledgement. This work is supported by the project GEOCRADLE (Coordinating and integRating state-of-the-art Earth Observation Activities in the regions of North Africa, Middle East, and Balkans and Developing Links with GEO related initiatives towards GEOSS), grant agreement no. 690133, funded through the European Union Horizon 2020 Programme - Topic: SC5-18b-2015, Integrating North African, Middle East and Balkan Earth Observation capacities in GEOSS. We would also like to acknowledge the support for international research staff exchange through the REQUA (Regional climate-air quality interactions) project (FP7-PEOPLE-2013-IRSES - Marie Curie Action, PIRSES-GA-2013-612671) and ACTRIS-2 project (grant agreement no. 654109, funded through the European Union's Horizon 2020 programme). CALIPSO data were provided by NASA. The LIVAS team thanks the ICARE Data and Services Center (http://www.icare.univ-lille1.fr/) for providing access to CALIPSO data used for the production of the LIVAS dataset.

Edited by: K. Tsigaridis

Reviewed by: three anonymous referees

\section{References}

Alexandri, G., Georgoulias, A. K., Zanis, P., Katragkou, E., Tsikerdekis, A., Kourtidis, K., and Meleti, C.: On the ability of RegCM4 regional climate model to simulate surface solar radiation patterns over Europe: an assessment using satellitebased observations, Atmos. Chem. Phys., 15, 13195-13216, doi:10.5194/acp-15-13195-2015, 2015.

Alfaro, S. C. and Gomes, L.: Modeling mineral aerosol production by wind erosion: Emission intensities and aerosol size distributions in source areas, J. Geophys. Res., 106, 18075, doi:10.1029/2000JD900339, 2001.

Alfaro, S. C., Gaudichet, A., Gomes, L., and Maillé, M.: Modeling the size distribution of a soil aerosol produced by sandblasting, J. Geophys. Res., 102, 11239, doi:10.1029/97JD00403, 1997.

Alfaro, S. C., Gaudichet, A., Gomes, L., and Maillé, M.: Mineral aerosol production by wind erosion: Aerosol particle sizes and binding energies, Geophys. Res. Lett., 25, 991-994, doi:10.1029/98GL00502, 1998.

Ali, A. and Lebel, T.: The Sahelian standardized rainfall index revisited, Int. J. Climatol., 29, 1705-1714, doi:10.1002/joc.1832, 2009.

Alpert, P., Kishcha, P., Shtivelman, A., Krichak, S., and Joseph, J.: Vertical distribution of Saharan dust based on 2.5-year model predictions, Atmos. Res., 70, 109-130, doi:10.1016/j.atmosres.2003.11.001, 2004.

Amiridis, V., Wandinger, U., Marinou, E., Giannakaki, E., Tsekeri, A., Basart, S., Kazadzis, S., Gkikas, A., Taylor, M., Baldasano, J., and Ansmann, A.: Optimizing CALIPSO Saharan dust retrievals, Atmos. Chem. Phys., 13, 12089-12106, doi:10.5194/acp-1312089-2013, 2013.

Amiridis, V., Marinou, E., Tsekeri, A., Wandinger, U., Schwarz, A., Giannakaki, E., Mamouri, R., Kokkalis, P., Binietoglou, I., Solomos, S., Herekakis, T., Kazadzis, S., Gerasopoulos, E., Proestakis, E., Kottas, M., Balis, D., Papayannis, A., Kontoes, C., Kourtidis, K., Papagiannopoulos, N., Mona, L., Pappalardo, G., Le Rille, O., and Ansmann, A.: LIVAS: a 3-D multi-wavelength aerosol/cloud database based on CALIPSO and EARLINET, Atmos. Chem. Phys., 15, 7127-7153, doi:10.5194/acp-15-71272015, 2015.

Baars, H., Kanitz, T., Engelmann, R., Althausen, D., Heese, B., Komppula, M., Preißler, J., Tesche, M., Ansmann, A., Wandinger, U., Lim, J.-H., Ahn, J. Y., Stachlewska, I. S., Amiridis, V., Marinou, E., Seifert, P., Hofer, J., Skupin, A., Schneider, F., Bohlmann, S., Foth, A., Bley, S., Pfüller, A., Giannakaki, E., Lihavainen, H., Viisanen, Y., Hooda, R. K., Pereira, S. N., Bortoli, D., Wagner, F., Mattis, I., Janicka, L., Markowicz, 
K. M., Achtert, P., Artaxo, P., Pauliquevis, T., Souza, R. A. F., Sharma, V. P., van Zyl, P. G., Beukes, J. P., Sun, J., Rohwer, E. G., Deng, R., Mamouri, R.-E., and Zamorano, F.: An overview of the first decade of Polly ${ }^{\text {NET }}$ : an emerging network of automated Raman-polarization lidars for continuous aerosol profiling, Atmos. Chem. Phys., 16, 5111-5137, doi:10.5194/acp-165111-2016, 2016.

Bangert, M., Nenes, A., Vogel, B., Vogel, H., Barahona, D., Karydis, V. A., Kumar, P., Kottmeier, C., and Blahak, U.: Saharan dust event impacts on cloud formation and radiation over Western Europe, Atmos. Chem. Phys., 12, 4045-4063, doi:10.5194/acp-124045-2012, 2012.

Basart, S., Pérez, C., Nickovic, S., Cuevas, E., and Baldasano, J. M.: Development and evaluation of the BSCDREAM8b dust regional model over Northern Africa, the Mediterranean and the Middle East, Tellus B, 64, 1-23, doi:10.3402/tellusb.v64i0.18539, 2012.

Boucher, O., Randall, D., Artaxo, P., Bretherton, C., Feingold, G., Forster, P., Kerminen, V.-M., Kondo, Y., Liao, H., Lohmann, U., Rasch, P., Satheesh, S. K., Sherwood, S., Stevens, B., and Zhang, X.: The Physical Science Basis, in: Contribution of Working Group I to the Fifth Assessment Report of the Intergovernmental Panel on Climate Change, edited by: Stocker, T. F., Qin, D., Plattner, G.-K., Tignor, M., Allen, S. K., Boschung, J., Nauels, A., Xia, Y., Bex, V., and Midg, P. M., 2013.

Bretherton, C. S., McCaa, J. R., and Grenier, H.: A New Parameterization for Shallow Cumulus Convection and Its Application to Marine Subtropical Cloud-Topped Boundary Layers. Part I: Description and 1D Results, Mon. Weather Rev., 132, 864-882, doi:10.1175/1520-0493(2004)132<0864:ANPFSC >2.0.CO;2, 2004.

Bristow, C. S., Hudson-Edwards, K. A., and Chappell, A.: Fertilizing the Amazon and equatorial Atlantic with West African dust, Geophys. Res. Lett., 37, L14807, doi:10.1029/2010GL043486, 2010.

Dee, D. P., Uppala, S. M., Simmons, A. J., Berrisford, P., Poli, P., Kobayashi, S., Andrae, U., Balmaseda, M. A., Balsamo, G., Bauer, P., Bechtold, P., Beljaars, A. C. M., van de Berg, L., Bidlot, J., Bormann, N., Delsol, C., Dragani, R., Fuentes, M., Geer, A. J., Haimberger, L., Healy, S. B., Hersbach, H., Hólm, E. V, Isaksen, L., Kållberg, P., Köhler, M., Matricardi, M., McNally, A. P., Monge-Sanz, B. M., Morcrette, J.-J., Park, B.-K., Peubey, C., de Rosnay, P., Tavolato, C., Thépaut, J.-N., and Vitart, F.: The ERA-Interim reanalysis: configuration and performance of the data assimilation system, Q. J. Roy. Meteorol. Soc., 137, 553597, doi:10.1002/qj.828, 2011.

Dickinson, R. E., Henderson-Sellers, A., and Kennedy, P. J.: Biosphere-Atmosphere Transfer Scheme (BATS) Version 1e as Coupled to the NCAR Community Climate Codel. NCAR/TN-387+STR, Boulder, Colorado, available at: http://scholar.google.com/scholar?hl=en\&btnG=Search\&q= intitle:Biosphere-Atmosphere+Transfer+Scheme+(+BATS+ )+Version+le+as+Coupled+to+the+NCAR+Community+ Climate+Model\#8 (last access: 26 May 2015), 1993.

Engelstaedter, S., Tegen, I., and Washington, R.: North African dust emissions and transport, Earth-Sci. Rev., 79, 73-100, doi:10.1016/j.earscirev.2006.06.004, 2006.
Engelstaedter, S. and Washington, R.: Temporal controls on global dust emissions: The role of surface gustiness, Geophys. Res. Lett., 34, L15805, doi:10.1029/2007GL029971, 2007.

Foret, G., Bergametti, G., Dulac, F., and Menut, L.: An optimized particle size bin scheme for modeling mineral dust aerosol, J. Geophys. Res., 111, D17310, doi:10.1029/2005JD006797, 2006.

Georgoulias, A. K., Alexandri, G., Kourtidis, K. A., Lelieveld, J., Zanis, P., and Amiridis, V.: Differences between the MODIS Collection 6 and 5.1 aerosol datasets over the greater Mediterranean region, Atmos. Environ., 147, 310-319, doi:10.1016/j.atmosenv.2016.10.014, 2016a.

Georgoulias, A. K., Alexandri, G., Kourtidis, K. A., Lelieveld, J., Zanis, P., Pöschl, U., Levy, R., Amiridis, V., Marinou, E., and Tsikerdekis, A.: Spatiotemporal variability and contribution of different aerosol types to the aerosol optical depth over the Eastern Mediterranean, Atmos. Chem. Phys., 16, 13853-13884, doi:10.5194/acp-16-13853-2016, 2016b.

Giorgi, F. and Anyah, R.: INTRODUCTION The road towards RegCM4 F. Giorgi1*, R. O. Anyah2, Clim. Res., 52, 3-6, doi:10.3354/cr01089, 2012.

Giorgi, F., Coppola, E., Solmon, F., Mariotti, L., Sylla, M., Bi, X., Elguindi, N., Diro, G., Nair, V., Giuliani, G., Turuncoglu, U., Cozzini, S., Güttler, I., O’Brien, T., Tawfik, A., Shalaby, a, Zakey, A., Steiner, A., Stordal, F., Sloan, L., and Brankovic, C.: RegCM4: model description and preliminary tests over multiple CORDEX domains, Clim. Res., 52, 7-29, doi:10.3354/cr01018, 2012.

Gkikas, A., Hatzianastassiou, N., Mihalopoulos, N., Katsoulis, V., Kazadzis, S., Pey, J., Querol, X., and Torres, O.: The regime of intense desert dust episodes in the Mediterranean based on contemporary satellite observations and ground measurements, Atmos. Chem. Phys., 13, 12135-12154, doi:10.5194/acp-1312135-2013, 2013.

Gong, S. L.: Canadian Aerosol Module: A size-segregated simulation of atmospheric aerosol processes for climate and air quality models 1. Module development, J. Geophys. Res., 108, 4007, doi:10.1029/2001JD002002, 2003.

Goudie, A. S. and Middleton, N. J.: Saharan dust storms: nature and consequences, Earth-Sci. Rev., 56, 179-204, doi:10.1016/S00128252(01)00067-8, 2001.

Grell, G. A., Dudhia, J., and Stauffer, D. R.: A Description of the Fifth-Generation Penn State/NCAR Mesoscale Model (MM5), National Center for Atmospheric Research, Boulder, Colorado, 1994.

Hänel, A., Baars, H., Althausen, D., Ansmann, A., Engelmann, R., and Sun, J. Y.: One-year aerosol profiling with EUCAARI Raman lidar at Shangdianzi GAW station: Beijing plume and seasonal variations, J. Geophys. Res.-Atmos., 117, D13201, doi:10.1029/2012JD017577, 2012.

Hansen, J., Sato, M., Lacis, A., and Ruedy, R.: The missing climate forcing, Philos. T. R. Soc. B, 352, 231-240, doi:10.1098/rstb.1997.0018, 1997.

Harris, I., Jones, P. D., Osborn, T. J., and Lister, D. H.: Updated high-resolution grids of monthly climatic observations - the CRU TS3.10 Dataset, Int. J. Climatol., 34, 623-642, doi:10.1002/joc.3711, 2014.

Holtslag, A. A. M., De Bruijn, E. I. F., and Pan, H.-L.: A High Resolution Air Mass Transformation Model for Short-Range Weather Forecasting, Mon. Weather Rev., 118, 1561-1575, 
doi:10.1175/1520-0493(1990)118<1561:AHRAMT>2.0.CO;2, 1990.

Huneeus, N., Schulz, M., Balkanski, Y., Griesfeller, J., Prospero, J., Kinne, S., Bauer, S., Boucher, O., Chin, M., Dentener, F., Diehl, T., Easter, R., Fillmore, D., Ghan, S., Ginoux, P., Grini, A., Horowitz, L., Koch, D., Krol, M. C., Landing, W., Liu, X., Mahowald, N., Miller, R., Morcrette, J.-J., Myhre, G., Penner, J., Perlwitz, J., Stier, P., Takemura, T., and Zender, C. S.: Global dust model intercomparison in AeroCom phase I, Atmos. Chem. Phys., 11, 7781-7816, doi:10.5194/acp-11-7781-2011, 2011.

Iacono, M. J., Mlawer, E. J., Clough, S. A., and Morcrette, J.-J.: Impact of an improved longwave radiation model, RRTM, on the energy budget and thermodynamic properties of the NCAR community climate model, CCM3, J. Geophys. Res., 105, 14873, doi:10.1029/2000JD900091, 2000.

Israelevich, P., Ganor, E., Alpert, P., Kishcha, P., and Stupp, A.: Predominant transport paths of Saharan dust over the Mediterranean Sea to Europe, J. Geophys. Res., 117, D02205, doi:10.1029/2011JD016482, 2012.

Israelevich, P. L.: Annual variations of physical properties of desert dust over Israel, J. Geophys. Res., 108, 4381, doi:10.1029/2002JD003163, 2003.

Iversen, J. D. and White, B. R.: Saltation threshold on Earth, Mars and Venus, Sedimentology, 29, 111-119, doi:10.1111/j.13653091.1982.tb01713.x, 1982.

Karydis, V. A., Kumar, P., Barahona, D., Sokolik, I. N., and Nenes, A.: On the effect of dust particles on global cloud condensation nuclei and cloud droplet number, J. Geophys. Res.-Atmos., 116, D23204, doi:10.1029/2011JD016283, 2011.

Kiehl, J. T., Hack, J. J., Bonan, G. B., Boville, B. A., Briegleb, B. P., Williamson, D. L., and Rasch, P. J.: Description of the NCAR Community Climate Model (CCM3), National Center for Atmospheric Research, Boulder, Colorado, 1996.

Kinne, S.: Monthly averages of aerosol properties: A global comparison among models, satellite data, and AERONET ground data, J. Geophys. Res., 108, 4634, doi:10.1029/2001JD001253, 2003.

Knippertz, P. and Stuut, J.-B. W.: Mineral Dust, edited by: Knippertz, P. and Stuut, J.-B. W., Springer Netherlands, Dordrecht, 2014.

Kok, J. F.: A scaling theory for the size distribution of emitted dust aerosols suggests climate models underestimate the size of the global dust cycle, P. Natl. Acad. Sci. USA, 108, 1016-1021, doi:10.1073/pnas.1014798108, 2011a.

Kok, J. F.: Does the size distribution of mineral dust aerosols depend on the wind speed at emission?, Atmos. Chem. Phys., 11, 1014910156, doi:10.5194/acp-11-10149-2011, $2011 \mathrm{~b}$.

Laurent, B., Marticorena, B., Bergametti, G., Léon, J. F., and Mahowald, N. M.: Modeling mineral dust emissions from the Sahara desert using new surface properties and soil database, J. Geophys. Res., 113, D14218, doi:10.1029/2007JD009484, 2008.

Liao, H. and Seinfeld, J. H.: Radiative forcing by mineral dust aerosols: Sensitivity to key variables, J. Geophys. Res.-Atmos., 103, 31637-31645, doi:10.1029/1998JD200036, 1998.

Liu, Z., Vaughan, M., Winker, D., Kittaka, C., Getzewich, B., Kuehn, R., Omar, A., Powell, K., Trepte, C., and Hostetler, C.: The CALIPSO Lidar Cloud and Aerosol Discrimination: Version 2 Algorithm and Initial Assessment of
Performance, J. Atmos. Ocean. Technol., 26, 1198-1213, doi:10.1175/2009JTECHA1229.1, 2009.

Lohmann, U. and Feichter, J.: Can the direct and semi-direct aerosol effect compete with the indirect effect on a global scale?, Geophys. Res. Lett., 28, 159-161, doi:10.1029/2000GL012051, 2001.

Marticorena, B. and Bergametti, G.: Modeling the atmospheric dust cycle: 1 . Design of a soil-derived dust emission scheme, J. Geophys. Res., 100, 16415, doi:10.1029/95JD00690, 1995.

Menut, L., Forêt, G., and Bergametti, G.: Sensitivity of mineral dust concentrations to the model size distribution accuracy, J. Geophys. Res., 112, D10210, doi:10.1029/2006JD007766, 2007.

Menut, L., Pérez, C., Haustein, K., Bessagnet, B., Prigent, C., and Alfaro, S.: Impact of surface roughness and soil texture on mineral dust emission fluxes modeling, J. Geophys. Res.-Atmos., 118, 6505-6520, doi:10.1002/jgrd.50313, 2013.

Mlawer, E. J. and Clough, S. A.: On the Extension of Rapid Radiative Transfer Model to the Shortwave Region Longwave Method and, US Department of Energy, CONF-9603149, 1997.

Mlawer, E. J., Taubman, S. J., Brown, P. D., Iacono, M. J., and Clough, S. A.: Radiative transfer for inhomogeneous atmospheres: RRTM, a validated correlated-k model for the longwave, J. Geophys. Res., 102, 16663, doi:10.1029/97JD00237, 1997.

Moulin, C., Lambert, C. E., Dayan, U., Masson, V., Ramonet, M., Bousquet, P., Legrand, M., Balkanski, Y. J., Guelle, W., Marticorena, B., Bergametti, G., and Dulac, F.: Satellite climatology of African dust transport in the Mediterranean atmosphere, J. Geophys. Res., 103, 13137, doi:10.1029/98JD00171, 1998.

Nabat, P., Solmon, F., Mallet, M., Kok, J. F., and Somot, S.: Dust emission size distribution impact on aerosol budget and radiative forcing over the Mediterranean region: a regional climate model approach, Atmos. Chem. Phys., 12, 10545-10567, doi:10.5194/acp-12-10545-2012, 2012.

Nabat, P., Somot, S., Mallet, M., Sevault, F., Chiacchio, M., and Wild, M.: Direct and semi-direct aerosol radiative effect on the Mediterranean climate variability using a coupled regional climate system model, Clim. Dynam., 44, 1127-1155, doi:10.1007/s00382-014-2205-6, 2014.

Nicholson, S. E.: The West African Sahel: A Review of Recent Studies on the Rainfall Regime and Its Interannual Variability, ISRN Meteorol., 1-32, doi:10.1155/2013/453521, 2013.

Oleson, K. W., Lawrence, D. M., Bonan, G. B., Drewniak, B., Huang, M., Charles, D., Levis, S., Li, F., Riley, W. J., Zachary, M., Swenson, S. C., Thornton, P. E., Bozbiyik, A., Fisher, R., Heald, C. L., Kluzek, E., Lamarque, F., Lawrence, P. J., Leung, L. R., Muszala, S., Ricciuto, D. M., and Sacks, W.: Technical Description of version 4.5 of the Community Land Model (CLM) Coordinating, NCAR/TN-503+STR NCAR, Boulder, Colorado, 2013.

Omar, A. H., Winker, D. M., Vaughan, M. A., Hu, Y., Trepte, C. R., Ferrare, R. A., Lee, K.-P., Hostetler, C. A., Kittaka, C., Rogers, R. R., Kuehn, R. E., and Liu, Z.: The CALIPSO Automated Aerosol Classification and Lidar Ratio Selection Algorithm, J. Atmos. Ocean. Technol., 26, 1994-2014, doi:10.1175/2009JTECHA1231.1, 2009.

Pal, J. S., Small, E. E., and Eltahir, E. A. B.: Simulation of regionalscale water and energy budgets: Representation of subgrid cloud and precipitation processes within RegCM, J. Geophys. Res.Atmos., 105, 29579-29594, doi:10.1029/2000JD900415, 2000. 
Pincus, R.: A fast, flexible, approximate technique for computing radiative transfer in inhomogeneous cloud fields, J. Geophys. Res., 108, 4376, doi:10.1029/2002JD003322, 2003.

Prospero, J. M., Ginoux, P., Torres, O., Nicholson, S. E., and Gill, T. E.: Environmental characterization of global sources of atmospheric soil dust identified with the NIMBUS 7 Total Ozone Mapping Spectrometer (TOMS) absorbing aerosol product, Rev. Geophys., 40, 1002, doi:10.1029/2000RG000095, 2002.

Ramanathan, V., Crutzen, P. J., Kiehl, J. T., and Rosenfeld, D.: Aerosols, climate, and the hydrological cycle, Science, 294, 2119-24, doi:10.1126/science.1064034, 2001.

Ridley, D. A., Heald, C. L., and Ford, B.: North African dust export and deposition: A satellite and model perspective, J. Geophys. Res., 117, D02202, doi:10.1029/2011JD016794, 2012.

Rodríguez, S., Cuevas, E., Prospero, J. M., Alastuey, A., Querol, X., López-Solano, J., García, M. I., and Alonso-Pérez, S.: Modulation of Saharan dust export by the North African dipole, Atmos. Chem. Phys., 15, 7471-7486, doi:10.5194/acp-15-74712015, 2015.

Ryder, C. L., Highwood, E. J., Rosenberg, P. D., Trembath, J., Brooke, J. K., Bart, M., Dean, A., Crosier, J., Dorsey, J., Brindley, H., Banks, J., Marsham, J. H., McQuaid, J. B., Sodemann, H., and Washington, R.: Optical properties of Saharan dust aerosol and contribution from the coarse mode as measured during the Fennec 2011 aircraft campaign, Atmos. Chem. Phys., 13, 303325, doi:10.5194/acp-13-303-2013, 2013.

Sayer, A. M., Hsu, N. C., Bettenhausen, C., Jeong, M.-J., and Meister, G.: Effect of MODIS Terra radiometric calibration improvements on Collection 6 Deep Blue aerosol products: Validation and Terra/Aqua consistency, J. Geophys. Res.-Atmos., 120, 12157-12174, doi:10.1002/2015JD023878, 2015.

Sayer, A. M., Munchak, L. A., Hsu, N. C., Levy, R. C., Bettenhausen, C., and Jeong, M.-J.: MODIS Collection 6 aerosol products: Comparison between Aqua's e-Deep Blue, Dark Target, and "merged" data sets, and usage recommendations, J. Geophys. Res.-Atmos., 119, 13965-13989, doi:10.1002/2014JD022453, 2014.

Schuster, G. L., Vaughan, M., MacDonnell, D., Su, W., Winker, D., Dubovik, O., Lapyonok, T., and Trepte, C.: Comparison of CALIPSO aerosol optical depth retrievals to AERONET measurements, and a climatology for the lidar ratio of dust, Atmos. Chem. Phys., 12, 7431-7452, doi:10.5194/acp-12-7431-2012, 2012.

Seinfeld, J. H. and Pandis, S. N.: Atmospheric Chemistry and Physics: From Air Pollution to Climate Change, 1998.

Shalaby, A., Zakey, A. S., Tawfik, A. B., Solmon, F., Giorgi, F., Stordal, F., Sillman, S., Zaveri, R. A., and Steiner, A. L.: Implementation and evaluation of online gas-phase chemistry within a regional climate model (RegCM-CHEM4), Geosci. Model Dev., 5, 741-760, doi:10.5194/gmd-5-741-2012, 2012.

Shao, Y. and Lu, H.: A simple expression for wind erosion threshold friction velocity, J. Geophys. Res., 105, 437-443, 2000.

Solmon, F., Giorgi, F., and Liousse, C.: Aerosol modelling for regional climate studies: application to anthropogenic particles and evaluation over a European/African domain, Tellus B, 58, 51-72, doi:10.1111/j.1600-0889.2005.00155.x, 2006.
Solmon, F., Mallet, M., Elguindi, N., Giorgi, F., Zakey, A., and Konaré, A.: Dust aerosol impact on regional precipitation over western Africa, mechanisms and sensitivity to absorption properties, Geophys. Res. Lett., 35, L24705, doi:10.1029/2008GL035900, 2008.

Spyrou, C., Kallos, G., Mitsakou, C., Athanasiadis, P., Kalogeri, C., and Iacono, M. J.: Modeling the radiative effects of desert dust on weather and regional climate, Atmos. Chem. Phys., 13, 54895504, doi:10.5194/acp-13-5489-2013, 2013.

Steiner, A., Tawfik, A., Shalaby, A., Zakey, A., Abdel-Wahab, M., Salah, Z., Solmon, F., Sillman, S., and Zaveri, R.: Climatological simulations of ozone and atmospheric aerosols in the Greater Cairo region, Clim. Res., 59, 207-228, doi:10.3354/cr01211, 2014.

Tegen, I.: Modeling the mineral dust aerosol cycle in the climate system, Quaternary Sci. Rev., 22, 1821-1834, doi:10.1016/S0277-3791(03)00163-X, 2003.

Tegen, I., Koch, D., Lacis, A. A., and Sato, M.: Trends in tropospheric aerosol loads and corresponding impact on direct radiative forcing between 1950 and 1990: A model study, J. Geophys. Res., 105, 26971, doi:10.1029/2000JD900280, 2000.

Tesche, M., Wandinger, U., Ansmann, A., Althausen, D., Müller, D., and Omar, A. H.: Ground-based validation of CALIPSO observations of dust and smoke in the Cape Verde region, J. Geophys. Res.-Atmos., 118, 2889-2902, doi:10.1002/jgrd.50248, 2013.

Tiedtke, M.: A Comprehensive Mass Flux Scheme for $\mathrm{Cu}$ mulus Parameterization in Large-Scale Models, Mon. Weather Rev., 117, 1779-1800, doi:10.1175/15200493(1989)117<1779:ACMFSF>2.0.CO;2, 1989.

Vaughan, M. A., Powell, K. A., Winker, D. M., Hostetler, C. A., Kuehn, R. E., Hunt, W. H., Getzewich, B. J., Young, S. A., Liu, Z., and McGill, M. J.: Fully Automated Detection of Cloud and Aerosol Layers in the CALIPSO Lidar Measurements, J. Atmos. Ocean. Technol., 26, 2034-2050, doi:10.1175/2009JTECHA1228.1, 2009.

Wandinger, U., Tesche, M., Seifert, P., Ansmann, A., Müller, D., and Althausen, D.: Size matters: Influence of multiple scattering on CALIPSO light-extinction profiling in desert dust, Geophys. Res. Lett., 37, L10801, doi:10.1029/2010GL042815, 2010.

Winker, D. M., Vaughan, M. A., Omar, A., Hu, Y., Powell, K. A., Liu, Z., Hunt, W. H., and Young, S. A.: Overview of the CALIPSO Mission and CALIOP Data Processing Algorithms, J. Atmos. Ocean. Technol., 26, 2310-2323, doi:10.1175/2009JTECHA1281.1, 2009.

Young, S. A. and Vaughan, M. A.: The Retrieval of Profiles of Particulate Extinction from Cloud-Aerosol Lidar Infrared Pathfinder Satellite Observations (CALIPSO) Data: Algorithm Description, J. Atmos. Ocean. Technol., 26, 1105-1119, doi:10.1175/2008JTECHA1221.1, 2009.

Zakey, A. S., Solmon, F., and Giorgi, F.: Implementation and testing of a desert dust module in a regional climate model, Atmos. Chem. Phys., 6, 4687-4704, doi:10.5194/acp-6-4687-2006, 2006.

Zakey, A. S., Giorgi, F., and Bi, X.: Modeling of sea salt in a regional climate model: Fluxes and radiative forcing, J. Geophys. Res., 113, D14221, doi:10.1029/2007JD009209, 2008. 
Zender, C. S.: Mineral Dust Entrainment and Deposition (DEAD) model: Description and 1990s dust climatology, J. Geophys. Res., 108, 4416, doi:10.1029/2002JD002775, 2003.
Zhang, L.: A size-segregated particle dry deposition scheme for an atmospheric aerosol module, Atmos. Environ., 35, 549-560, doi:10.1016/S1352-2310(00)00326-5, 2001. 